\title{
USE OF GEOSPATIAL TOOLS IN MORPHOMETRIC ANALYSIS AND PRIORITISATION OF SUB-CATCHMENTS OF THE SOUNGROUGROU (CASAMANCE BASIN)
}

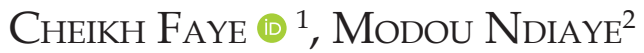 \\ ${ }^{1}$ Department of Geography, U.F.R. Sciences and Technologies, Assane Seck University of Ziguinchor, \\ Ziguinchor, Senegal \\ ${ }^{2}$ Centre de formation continue, Faculté des Sciences et Techniques, Université Sultane Moulay Slimane, \\ Béni Mellal, Morocco
}

Manuscript received: May 22, 2021

Revised version: July 02, 2021

Faye C., Ndiaye M., 2021. Use of geospatial tools in morphometric analysis and prioritisation of sub-catchments of the soundgrougrou (Casamance Basin). Quaestiones Geographicae 40(3), Bogucki Wydawnictwo Naukowe, Poznań, pp. 65-84. 9 tables, 7 figs.

AвSTRACт: The prioritisation of catchments, particularly in the context of catchment plans and management programmes, is part of water resources development. In fact, morphometric analysis assisted by geospatial technology is carried out by prioritising sub-catchments according to their natural resource availability characteristics. Information on the geomorphology and erosion factors of the study area is used in the area in the preparation of local models of ungauged sub-catchments, which otherwise lack an adequate hydrological database. The objective of this paper is to use geographic information systems (GISs) in morphometric analysis to prioritise sub-catchments of the Soungrougrou (a tributary of the Casamance River). In this respect, the integrated methodology involving morphometric aspects from geospatial technology is used. To carry out the geospatial research, basic mathematical equations used in a GIS environment were used to measure a series of aspects of hydrology such as flow length, flow length ratio, bifurcation ratio, drainage density, drainage texture, flow frequency, elongation rate, circularity ratio, form factor, relief and relief ratio. The results divided the whole catchment into three priority areas, namely high, medium and low. The results are relevant for establishing soil and water conservation plans in the Soungrougrou basin, as well as adequate groundwater production and management. The high category (sub-basins 6, 8, 14, 17 and 18) is subject to maximum soil erosion, which requires immediate intervention to avoid possible natural hazards.

KEYWORDS: DEM, morphometric aspects, prioritisation, erosion, Soungrougrou basin

Corresponding author: Cheikh Faye, cheikh.faye@univ-zig.sn

\section{Introduction}

Since the first quarter of the 20th century, the watershed has been considered as an areal unit of geomorphological investigation, but as a basic geomorphological unit, these analyses are useful for the application of various morphometric techniques. The study of natural hazards in a catchment area requires a good hydrological, geological, geomorphological, ecological and climatic understanding to determine the factors that influence the occurrence of natural hazards (vegetation cover, slope, land use and drainage network). These indices are necessary to determine the prioritisation of catchments and thus plan a programme to combat natural hazards. 
The proper management of a watershed requires the use of Geographic Information Systems (GISs) techniques and Digital Elevation Models (DEMs), for a better assessment of the study area in terms of slope, drainage system, topography, geomorphology and lithology from geological maps (Benzougagh et al. 2016). These data were used in the analysis of the morphometric parameters of the Gambia River basin.

As a key resource for sustainable development, the issue of water has been included in many development documents and strategies at regional, national and global levels. As a result, various aspects of water-related issues have been incorporated into the Sustainable Development Goals (SDGs), a task achieved through the hard work and tireless efforts of various stakeholders. Today, due to rapid population growth, economic development and multiple impacts on natural resources, water continues to be a fundamental concern and a precious asset to be managed, especially due to the demographic pressure on water resources that is increasing day by day in Senegal. Furthermore, the watershed is a fundamental unit for the conservation and preservation of natural resources, as soil and water conservation is a crucial issue in its management, which remains essential in the economic and social development of any country (Nag 1998, Reddy et al. 2004, Das and Mukherjee 2005, Manojkumar et al. 2019).

Morphometric analysis is the dimensioning and mathematical investigation of the earth's surface, its shape, and the measurement of landforms (Clarke 1966). It is easy to understand the behaviour of the hydrological system (Agarwal 1998) to recognise hydrological features, and the results will be a valuable input for overall water resources management (Jawaharraj et al. 1998, Sree Devi et al. 2001, Rai et al. 2014, 2017, 2018). Horton (1940) and Strahler (1950) undertook morphometric studies in the field of hydrology with results involving the analysis of various linear, areal and landform parameters of catchments. These parameters are very important for watershed management and hydro-geomorphological study (Gaikwad, Bhagat 2018). Thus, quantitative analysis of morphometric parameters is of immense use in studies devoted to watershed evolution, and is very important for understanding the processes of topography and physical properties and erosion characteristics of soil. It also reflects the amount of erosion, waterlogging, flooding, drought etc., which greatly helps in understanding the rocks, climate, drainage, landform and vegetation cover in the watershed (Manojkumar et al. 2019).

Physiographic, morphometric (Zolekar, Bhagat 2015) and social parameters are closely associated with watershed planning and development. Many authors have used linear, aerial and landform aspects for watershed prioritisation in development projects (Aouragh, Essahlaoui 2014, Gabale, Pawar 2015, Gharde, Kothari 2016). In addition, Gebre et al. (2015) used information on the relationship between soil types and soil texture with morphometric parameters. Some researchers reported a relationship between land use/cover characteristics and morphology, slope, soil, land surface processes, climate, hydrology etc. as well as human activities (Romshoo et al. 2012, Gumma et al. 2014, Gashaw et al. 2017). Parameters such as geology and rainfall show less variation and influence on the development of micro-watersheds (Gaikwad, Bhagat 2018). However, parameters such as geology and rainfall show considerable influence on the formation and variation of sub-watershed characteristics in medium and major river basins (Gajbhiye et al. 2014, Rai et al. 2014), while population pressure is one of the causes of overexploitation of natural resources. Similarly, morphometric parameters are successfully used along with geology, rainfall and population distribution for the prioritisation of sub-catchments in a medium watershed. Thus, the study of different watershed properties becomes significant because of their consequence in landform development. It provides knowledge that is essential for river basin management strategies and the understanding of their hydrological properties.

The present study was carried out to understand the various morphometric aspects: linear, areal and relief of the sub-catchments of the Soungrougrou using geospatial techniques. Morphometric analysis using remote sensing and GIS techniques has been widely used for watershed prioritisation, analysis and management of sub-catchments (Khan et al. 2001, Vittal et al. 2004, Chopra et al. 2005, Ratnam et al. 2005). GIS 
techniques offer the potential for accurate and timely spatial information for watershed planning and management (Manojkumar et al. 2019).

The study of natural hazards in a catchment requires a good hydrological, geological, geomorphological, ecological and climatic understanding to determine the factors that influence the occurrence of natural hazards (vegetation cover, slope, land use and the river system). These indices are necessary to determine the prioritisation of watersheds and thus plan a programme for the fight against natural hazards (Benzougagh et al. 2016). The proper management of a watershed, as well as the study of the prioritisation of sub-watersheds, requires the use of GISs techniques and DEMs of the Shuttle Radar Topography Mission (SRTM) type, for a better assessment of the study area in terms of slope, drainage system, topography, geomorphology and lithology from geological maps. These data were used in the analysis of the morphometric parameters of the Soungrougrou watershed and the sub-basins, which allowed prioritisation of the watersheds for possible protection against flooding, salinisation and erosion risks.

\section{Study area}

The Casamance basin, which extends over three administrative regions (Ziguinchor, Sédhiou and Kolda) in the south of Senegal, is located in latitude between $12^{\circ} 20^{\prime}$ and $13^{\circ} 21^{\prime} \mathrm{N}$ and in longitude between $14^{\circ} 17.1^{\prime}$ and $16^{\circ} 47^{\prime} \mathrm{W}$ (Fig. 1). It covers an area of approximately $2150 \mathrm{~km}^{2}$ and stretches $270 \mathrm{~km}$ from west to east and $100 \mathrm{~km}$ from north to south (Dacosta 1989). It has an Atlantic and South Sudanian climate (Faye et al. 2020) and is strongly influenced by geographical and atmospheric factors (Sagna 2005).

The Casamance basin can be subdivided into three parts: the upper basin (Upper Casamance), the middle basin (Middle Casamance) and the lower basin (Lower Casamance). From a topographical point of view, the Casamance watershed is characterised by its low relief. Indeed, all the rivers have their source on the plateau of the terminal continent and the low slopes explain the deep invasion of the sea in the Casamance basin, causing the salinisation of agricultural land (PADERCA 2008).

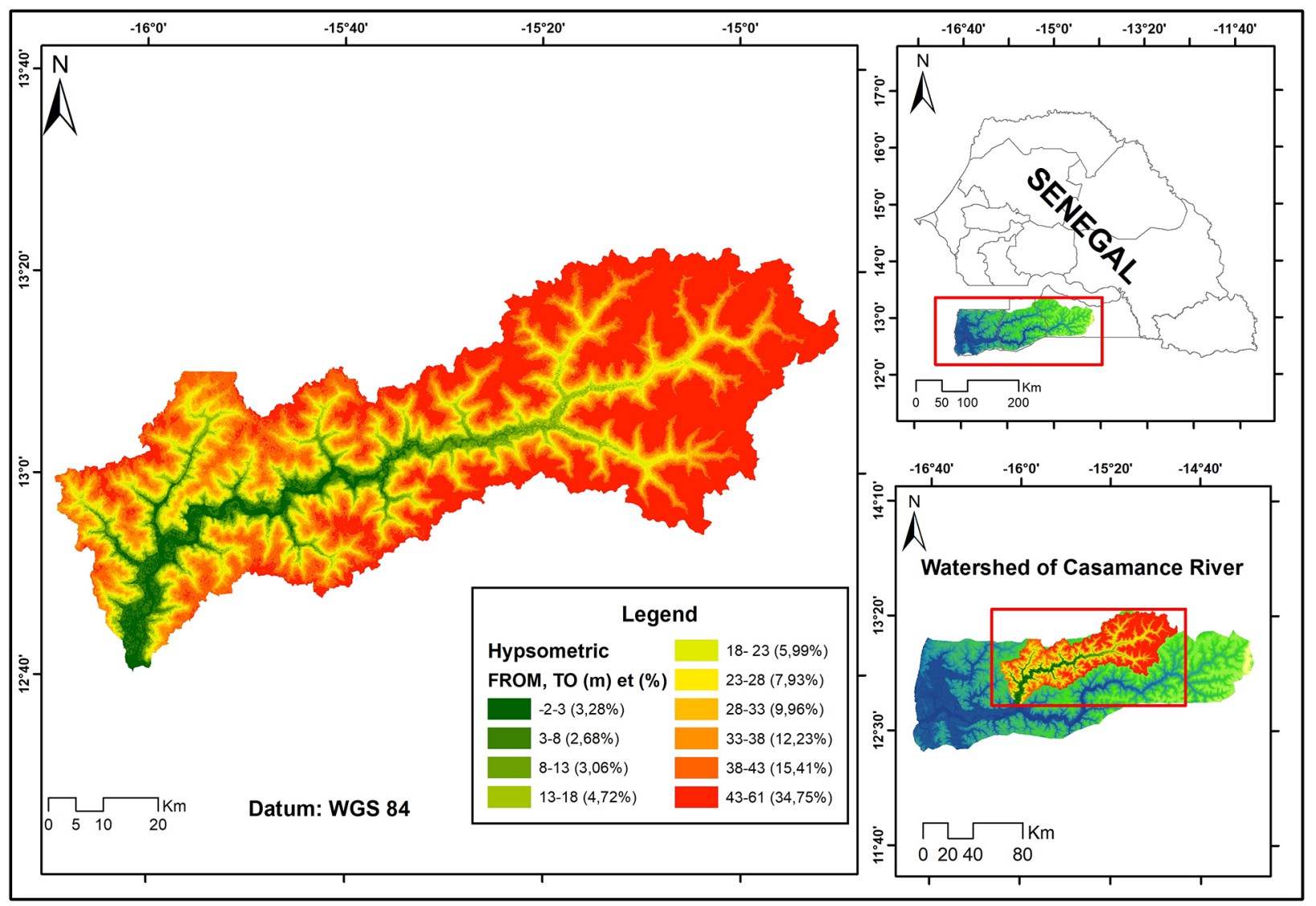

Fig. 1. Location of the Soungrougrou basin. 
Opposite Adéane is the confluence of the Casamance and the Soungrougrou, its most important tributary, formed, like the Casamance, by the union of several small tributaries that originate in the vast region of the Pata and Guimara forests. The Soungrougrou first flows in a west-south-west direction, forming loops. But at the 16th meridian, it turns south to join the Casamance. The Soungrougrou watershed covers an area of about $4800 \mathrm{~km}^{2}$. In the Soungrougrou basin, altitudes vary from $43 \mathrm{~m}$ in the Pata forest to $19 \mathrm{~m}$ at Diaw Ba near the confluence with the Casamance (Dacosta 1989). In this basin, the hydrographic network is essentially made up of perennial rivers. However, two types of flow have been identified: the zone where the flow is perennial, marked by a very pronounced salinisation process (Diaroumé-Dialambéré axis),

Table 1. Morphometric parameters.

\begin{tabular}{|c|c|c|}
\hline Morphometric parameters & Descriptions & References \\
\hline \multicolumn{3}{|c|}{ Linear aspects } \\
\hline Stream number $(\mathrm{Nu})$ & $\begin{array}{l}\mathrm{Nu}=\mathrm{N} 1+\mathrm{N} 2+\ldots \mathrm{Nn} \text {; where, } \mathrm{Lu}=\text { Length of the river, } \mathrm{L} 1=\text { Length } \\
\text { of the first-order river and } \mathrm{L} 2=\text { Length of the second-order river } \\
\text { and } \mathrm{Ln}=\text { Number ' } n \text { ' of the river length. }\end{array}$ & Strahler (1964) \\
\hline Stream length $(\mathrm{Lu})$ & $\begin{array}{l}\mathrm{Lu}=\mathrm{L} 1+\mathrm{L} 2 \ldots . . . ; \text { where, } \mathrm{N} 1=\text { First-order river, N2 = Second-order } \\
\text { river and Nn = Number of rivers }\end{array}$ & Strahler (1964) \\
\hline $\begin{array}{l}\text { Average length of flow } \\
\text { (Lum) }\end{array}$ & $\begin{array}{l}\mathrm{Lum}=\mathrm{Lu} / \mathrm{Nu} ; \text { where, } \mathrm{Lu}=\text { Length of rivers of a given order }(\mathrm{km}), \\
\mathrm{Nu}=\text { Number of river segments. }\end{array}$ & Strahler (1964) \\
\hline Flow length ratio (Lur) & $\begin{array}{l}\text { Lur }=\mathrm{Lu} / \mathrm{Lu}-1 ; \text { where, } \mathrm{Lu}=\text { Total length of the rivers of order }(\mathrm{u}) \text {, } \\
\mathrm{Lu}-1=\text { Total length of the rivers of the next lower order. }\end{array}$ & Strahler (1964) \\
\hline Bifurcation ratio $(\mathrm{Rb})$ & $\begin{array}{l}\mathrm{Rb}=\mathrm{Nu} / \mathrm{Nu}+1 ; \text { where, } \mathrm{Nu}=\text { Number of river segments present } \\
\text { in the given order, } \mathrm{Nu}+1=\text { Number of segments in the next higher } \\
\text { order. }\end{array}$ & Schumm (1956) \\
\hline Drainage density $(\mathrm{Dd})$ & $\begin{array}{l}\mathrm{Dd}=\mathrm{L} / \mathrm{A} \text {; where, } \mathrm{L}=\text { Total length of the river, } \mathrm{A}=\text { Area of the } \\
\text { basin. }\end{array}$ & Strahler (1964) \\
\hline Drainage texture $(\mathrm{Tj})$ & $\begin{array}{l}\mathrm{Tj}=\mathrm{Dd}{ }^{*} \mathrm{Nj} / \mathrm{A}, \text { where } \mathrm{Tj}=\text { Torrentiality coefficient of the order flow; } \\
\mathrm{Nj}=\text { Number of streams of order } \mathrm{j}, \mathrm{A}=\text { Basin area, } \mathrm{Dd}=\text { Drainage } \\
\text { density }\left(\mathrm{km} \times \mathrm{km}^{-2}\right)\end{array}$ & Strahler (1964) \\
\hline Flow frequency (Fs) & Fs $=N / A ;$ where,$L=$ Total number of rivers, $A=$ Area of the basin & Strahler (1964) \\
\hline Length of surface flow (Lo) & Lo $=1 / 2 \mathrm{Dd}$, where, $\mathrm{Dd}=$ Drainage density & Strahler (1964) \\
\hline Texture ratio (Rt) & $\begin{array}{l}\text { Rt }=\mathrm{N} 1 / \mathrm{P} ; \text { where, } \mathrm{N} 1=\text { Total number of first-order rivers, } \mathrm{P}=\text { Basin } \\
\text { perimeter }\end{array}$ & Strahler (1964) \\
\hline \multicolumn{3}{|c|}{ Formal aspects } \\
\hline $\begin{array}{l}\text { Gravelius Compactness } \\
\text { Coefficient (KG) }\end{array}$ & $\begin{array}{l}(\mathrm{KG})=0.25 \mathrm{P} / \mathrm{ÖA} \text {; where } \mathrm{KG}=\text { Gravelius compactness coefficient, } \\
\mathrm{P}=\text { Basin perimeter, } \mathrm{A}=\text { Basin area }\end{array}$ & Gravelius (1914) \\
\hline Form factor $(\mathrm{Ff})$ & $\begin{array}{l}\mathrm{Ff}=\mathrm{A} /(\mathrm{Lb})^{\wedge} 2 ; \text { where, } \mathrm{A}=\text { Area of the basin, } \mathrm{Lb}=\text { Length of the } \\
\text { basin }\end{array}$ & Strahler (1964) \\
\hline Basin shape (Bs) & $\mathrm{Bs}=\mathrm{Lb}^{\wedge} 2 / \mathrm{A}$; where $\mathrm{A}=$ Area of the basin, $\mathrm{Lb}=$ Length of the basin & Chorley (1957) \\
\hline Form factor $(\mathrm{k})$ & $\begin{array}{l}\mathrm{k}=\mathrm{Lb}^{\wedge} 2 \mathrm{p} / 4 \mathrm{~A} ; \text { where } \mathrm{A}=\text { Area of the basin, } \mathrm{p}=3.14, \mathrm{Lb}=\text { Length } \\
\text { of the basin }\end{array}$ & Chorley (1957) \\
\hline Circularity ratio $(\mathrm{Rc})$ & $\begin{array}{l}\mathrm{Rc}=4 \mathrm{pA} / \mathrm{P}^{\wedge} 2 ; \text { where } \mathrm{A}=\text { Area of the basin, } \mathrm{p}=3.14, \mathrm{P}=\text { Perimeter } \\
\text { of the basin. }\end{array}$ & Miller (1953) \\
\hline Elongation ratio $(\mathrm{Ra})$ & $\begin{array}{l}\mathrm{Ra}=\ddot{O}(\mathrm{~A} / \mathrm{p}) / \mathrm{Lb} ; \text { where, } \mathrm{A}=\text { Area of the basin, } \mathrm{p}=3.14 \\
\mathrm{Lb}=\text { Length of the basin }\end{array}$ & Schumm (1956) \\
\hline $\begin{array}{l}\text { Constant channel mainte- } \\
\text { nance }(C)\end{array}$ & $\mathrm{C}=1 / \mathrm{Dd}$, where $\mathrm{Dd}=$ Drainage density & Strahler (1964) \\
\hline \multicolumn{3}{|c|}{ Terrain aspects } \\
\hline Basin relief $(\mathrm{Rh})$ & Vertical distance between the lowest and highest point of the pool & Schumm (1956) \\
\hline Relief ratio (Rhl) & Rhl $=\mathrm{Bh} / \mathrm{Lb} ;$ where, $\mathrm{Bh}=$ Basin relief, $\mathrm{Lb}=$ Basin length & Schumm (1956) \\
\hline Relative relief $(\mathrm{Rr})$ & $\operatorname{Rr}=R h^{*} 100 / P$, where $R h=$ Basin relief, $P=$ Basin perimeter. & $\begin{array}{c}\text { Umair and Syed } \\
(2014)\end{array}$ \\
\hline Robustness number (Rn) & $\mathrm{Rn}=\mathrm{Bh}{ }^{\prime} \mathrm{Dd} ;$ where, $\mathrm{Bh}=$ Basin relief, $\mathrm{Dd}=$ Drainage density & Schumm (1956) \\
\hline Slope $(\mathrm{m})$ & $\begin{array}{l}m=D y / D x \text { or Rise } / \text { Run where, } m=\text { Slope, Dy is a vertical change, } \\
\text { Dx is a horizontal change }\end{array}$ & $\begin{array}{l}\text { Todhunter } \\
\text { (1888) }\end{array}$ \\
\hline
\end{tabular}


and an intermittent flow zone characterised by a certain aridity. These two types of flow require hydro-agricultural developments for the development of the basin (Faty 2011).

\section{Data and methods}

\section{Determination of morphometric aspects}

Morphometric aspects: linear, shape and relief aspects of the catchment were analysed (Horton 1945, Langbein 1947, Miller 1953, Schumm 1956, Smart and Surkan 1967, Mueller 1968,Strahler 1968, Manojkumar et al. 2019). The methodology adopted in this work is the use of topographic maps of the study area at a scale of 1:50,000, to validate the hydrographic network extracted from a DEM of the SRTM type with a resolution of $90 \mathrm{~m}$ (raster and vector topographic files provided by two American agencies: NASA and the NGA). Drainage basin parameters are derived from stream length, number of streams, basin area, perimeter and basin length. The morphometric parameters were calculated in this study using the formula proposed by Horton (1945), Miller (1953), Schumm (1956) and Strahler (1964).

The thematic maps were checked and modified based on information collected in the field using GPS (Global Positioning System) and fieldwork techniques. Initially, the topographic maps were georeferenced and the river network digitised in a GIS environment. The classification of the watercourses was carried out according to Horton's law. Linear aspects include stream order $(\mathrm{U})$, number of streams $(\mathrm{Nu})$, stream length $(\mathrm{Lu})$, bifurcation ratio $(\mathrm{Rb})$, average stream length of corresponding orders (Lum), stream length ratio (Lur) and average stream length ratio (Lurm). Spatial aspects include basin area $(\mathrm{A})$, basin perimeter $(\mathrm{P})$, stream frequency $(\mathrm{Fs})$, circularity ratio $(\mathrm{Rc})$, elongation ratio $(\mathrm{Ra})$, form factor $(\mathrm{Ff})$, overland flow length ( $\mathrm{Lg})$, texture ratio $(\mathrm{Rt})$, channel constancy $(\mathrm{C})$, drainage texture (Tj), Gravelius compactness coefficient $\left(\mathrm{K}_{\mathrm{G}}\right)$ and drainage density (Dd). Relief aspects include basin relief $(\mathrm{Rh})$, relief ratio $(\mathrm{Rhl})$, relative relief $(\mathrm{Rr})$, robustness number $(\mathrm{Rn})$ and slope analysis (m). All these parameters were calculated and analysed for the sub-catchments of the Soungrougrou (Table 1).

\section{Changes in land use and land cover}

The analysis of changes in land use and land cover is one of the important phenomena that have been treated with much attention in the recent past. For land use, we used Landsat images from 2000 and 2019. Two scenes were needed to cover the basin. The images (p204r051 and p205r051) are downloaded from http://earthexplorer.usgs.gov/, and have a resolution of $30 \mathrm{~m}$, which is satisfactory for mapping land use. The processing method is based on unsupervised clustering (Solly et al. 2020).

Land use and land cover categories such as cropland and bare soil, open woodland, very open woodland, water areas and other class consisting of tans and burns etc. were delineated based on image interpretation. The land use and land cover details from 2000 and 2019 were imported into Arcgis software for spatial analysis. The topology of each land use/land cover category was calculated both in $\mathrm{km}^{2}$ and as a percentage of the total area for 2000 and 2019. Information on land use/land cover changes can be obtained by image-to-image comparison or map-to-map comparison (Green et al. 1994). For the present study, a map-to-map comparison was used for the analysis of land use and land cover change (Akram and KhanImran, 2012).

\section{Sub-catchment hierarchy}

Catchment prioritisation is the order in which the various sub-catchments should be occupied to manage and protect the land. An appropriate mechanism for prioritisation of sub-catchments must therefore be developed. Morphometric Parameters are considered as erosion risk assessment parameters and have been used to prioritise sub-catchments (Bidwas et al 1999, Benzougagh et al. 2016, Moharir et al. 2021). Higher values of the linear parameters (Bifurcation Ratio, Drainage Density, Drainage Texture, Flow Frequency and Surface Flow Length) improve the runoff and thus erosion potential, while lower values of the shape parameters (Gravelius Compactness Coefficient, Shape Factor, Circularity Ratio, Basin Shape and Elongation Ratio) provide higher unit sediment rates. Thus, the entire sub-catchment was assessed according to the ranges of various geomorphological factors (Table 1). Thus, by 
calculating the composite parameter ranges, the priority ranking for all sub-catchments in the basin was made. The highest priority was given to the sub-catchment show with the lowest composite parameters. Indeed, based on the average value of these parameters, the sub-catchments with the low value are considered to be the highest priority, and the sub-catchment with the highest value of composite factor is the lowest priority.

\section{Results and discussion}

\section{Morphometric parameters}

\section{Linear parameters}

The linear parameters include flow number, flow order, flow length, flow ratio, flow frequency, drainage density, drainage texture, bifurcation ratio and surface flow duration (Tables 2 and 3 ).

\section{Number of watercourses $(\mathrm{Nu})$ and length of watercourse $(\mathrm{Lu})$}

Stream sequencing is the first step in quantitative watershed analysis. It expresses the hierarchical relationship between stream segments, their connectivity and the flow from the contributing catchments. Subsequently, this concept was adapted by Strahler (Pareta, Pareta 2011). According to Strahler (1980), first-order streams are those that have no tributaries. Second-order streams are tributaries of first-order channels only. Second-order channels join segments of third-order streams. Similarly, two third-order canals discharge water into fourth-order canals etc. The main river, through which all the water and sediment passes, is the first-order river segment. Thus, in the present study, the classification of the rivers is based on the method proposed by Strahler (1980) and constitutes a sixth-order river network. The maximum frequency is in the case of first-order streams and decreases as the stream order increases. Approximately 1317 streams were observed in the 20 sub-catchments of Soungrougrou (Fig. 2), of which 669 are first-order, 351 second-order, 164 third-order, 117 fourth-order and 6 fifth-order (Table 2 and Fig. 3). The drainage pattern of the Soungrougrou sub-catchments is dendritic (treelike), indicating a homogeneity of texture without structural control.

The maximum total length of the rivers is observed for the first-order rivers and decreases with increasing order. First-order rivers have a length of $932.5 \mathrm{~km}$, second-order rivers $534.6 \mathrm{~km}$, third-order rivers $239.1 \mathrm{~km}$, fourth-order rivers $139.6 \mathrm{~km}$ and fifth-order rivers $6.04 \mathrm{~km}$.

Table 2. Current analysis of the sub-catchments of the Soungrougrou catchment.

\begin{tabular}{|c|c|c|c|c|c|c|c|c|c|c|c|c|c|c|}
\hline \multirow{2}{*}{ Sub-basins } & \multicolumn{5}{|c|}{ Number of flows $(\mathrm{Nu})$} & \multicolumn{5}{|c|}{ Length of watercourse (Lu) } & \multicolumn{4}{|c|}{ Length ratio } \\
\hline & 1 & 2 & 3 & 4 & 5 & 1 & 2 & 3 & 4 & 5 & $2 / 1$ & $3 / 2$ & $4 / 3$ & $5 / 4$ \\
\hline SB1 & 217 & 100 & 65 & 45 & 6 & 340.30 & 144.10 & 95.22 & 62.45 & 8.04 & 0.92 & 1.02 & 0.95 & 0.97 \\
\hline SB 2 & 71 & 33 & 19 & 18 & - & 104.10 & 70.24 & 27.63 & 20.00 & - & 1.45 & 0.68 & 0.76 & - \\
\hline SB 3 & 7 & 5 & 1 & - & - & 11.68 & 11.48 & 2.14 & - & - & 1.38 & 0.93 & - & - \\
\hline SB 4 & 4 & 3 & - & - & - & 6.73 & 9.73 & - & - & - & 1.93 & - & - & - \\
\hline SB 5 & 4 & 3 & - & - & - & 4.43 & 8.39 & - & - & - & 2.53 & - & - & - \\
\hline SB 6 & 6 & 3 & 2 & - & - & 11.01 & 1.89 & 6.06 & & - & 0.34 & 4.81 & - & - \\
\hline SB 7 & 34 & 22 & 7 & 4 & - & 38.08 & 28.68 & 9.31 & 7.77 & - & 1.16 & 1.02 & 1.46 & - \\
\hline SB 8 & 9 & 8 & - & - & - & 13.15 & 12.42 & - & - & - & 1.06 & - & - & - \\
\hline SB 9 & 12 & 5 & 6 & & - & 13.04 & 5.23 & 9.24 & - & - & 0.96 & 1.47 & - & - \\
\hline SB 10 & 8 & 7 & - & - & - & 12.28 & 8.13 & - & - & - & 0.76 & - & - & - \\
\hline SB 11 & 28 & 17 & 6 & 4 & - & 33.30 & 27.30 & 7.30 & 5.17 & - & 1.35 & 0.76 & 1.06 & - \\
\hline SB 12 & 44 & 22 & 14 & 7 & - & 48.80 & 35.80 & 21.40 & 6.68 & - & 1.47 & 0.94 & 0.62 & - \\
\hline SB 13 & 33 & 14 & 5 & 14 & - & 44.40 & 26.40 & 7.29 & 13.20 & - & 1.40 & 0.77 & 0.65 & - \\
\hline SB 14 & 20 & 11 & 5 & - & - & 27.30 & 10.20 & 8.49 & - & - & 0.68 & 1.83 & - & - \\
\hline SB 15 & 7 & 4 & 1 & - & - & 13.00 & 6.15 & 0.98 & - & - & 0.83 & 0.64 & - & - \\
\hline SB 16 & 8 & 5 & - & - & - & 9.35 & 12.20 & - & - & - & 2.08 & - & - & - \\
\hline SB 17 & 20 & 13 & 4 & - & - & 19.10 & 18.60 & 9.22 & - & - & 1.50 & 1.61 & - & - \\
\hline SB 18 & 46 & 25 & 17 & - & - & 53.30 & 34.40 & 18.80 & - & - & 1.19 & 0.80 & - & - \\
\hline SB 19 & 82 & 44 & 12 & 25 & - & 118.00 & 58.20 & 16.00 & 24.40 & - & 0.92 & 1.01 & 0.73 & - \\
\hline SB 20 & 9 & 7 & - & - & - & 11.80 & 5.20 & - & - & - & 0.57 & - & - & - \\
\hline
\end{tabular}


Table 3. Linear parameters of the sub-catchments of the Soungrougrou catchment.

\begin{tabular}{|c|c|c|c|c|c|c|c|c|}
\hline $\begin{array}{c}\text { Sub- } \\
\text { basins }\end{array}$ & $\begin{array}{c}\text { Stream } \\
\text { number } \\
(\mathrm{Nu})\end{array}$ & $\begin{array}{c}\text { Stream } \\
\text { length (Lu) }\end{array}$ & $\begin{array}{c}\text { Flow length } \\
\text { ratio (Lur) }\end{array}$ & $\begin{array}{c}\text { Bifurcation } \\
\text { ratio (Rb) }\end{array}$ & $\begin{array}{c}\text { Drainage } \\
\text { density } \\
(\mathrm{Dd})\end{array}$ & $\begin{array}{c}\text { Drainage } \\
\text { texture (Tj) }\end{array}$ & $\begin{array}{c}\text { Flow fre- } \\
\text { quency (Fs) }\end{array}$ & $\begin{array}{c}\text { Length of } \\
\text { surface flow } \\
(\mathrm{Lo})\end{array}$ \\
\hline SB 1 & 433 & 650.11 & 0.962 & 3.163 & 0.476 & 0.151 & 0.317 & 0.238 \\
\hline SB 2 & 141 & 221.97 & 0.966 & 1.648 & 0.436 & 0.121 & 0.277 & 0.218 \\
\hline SB 3 & 13 & 25.30 & 1.154 & 3.200 & 0.409 & 0.086 & 0.210 & 0.205 \\
\hline SB 4 & 7 & 16.46 & 1.928 & 1.333 & 0.360 & 0.055 & 0.153 & 0.180 \\
\hline SB 5 & 7 & 12.82 & 2.525 & 1.333 & 0.390 & 0.083 & 0.213 & 0.195 \\
\hline SB 6 & 11 & 18.96 & 2.576 & 1.750 & 0.538 & 0.168 & 0.312 & 0.269 \\
\hline SB 7 & 67 & 83.84 & 1.215 & 2.146 & 0.502 & 0.202 & 0.401 & 0.251 \\
\hline SB 8 & 17 & 25.57 & 1.063 & 1.125 & 0.503 & 0.169 & 0.335 & 0.252 \\
\hline SB 9 & 23 & 27.51 & 1.217 & 1.617 & 0.487 & 0.198 & 0.407 & 0.243 \\
\hline SB 10 & 15 & 20.41 & 0.757 & 1.143 & 0.475 & 0.166 & 0.349 & 0.237 \\
\hline SB 11 & 55 & 73.06 & 1.057 & 1.993 & 0.461 & 0.160 & 0.347 & 0.230 \\
\hline SB 12 & 87 & 112.61 & 1.010 & 1.857 & 0.489 & 0.185 & 0.378 & 0.245 \\
\hline SB 13 & 66 & 91.26 & 0.941 & 1.838 & 0.485 & 0.170 & 0.351 & 0.243 \\
\hline SB 14 & 36 & 45.92 & 1.257 & 2.009 & 0.508 & 0.203 & 0.399 & 0.254 \\
\hline SB 15 & 12 & 20.10 & 0.734 & 2.875 & 0.439 & 0.115 & 0.262 & 0.220 \\
\hline SB 16 & 13 & 21.51 & 2.081 & 1.600 & 0.417 & 0.105 & 0.252 & 0.208 \\
\hline SB 17 & 37 & 46.87 & 1.555 & 2.394 & 0.504 & 0.201 & 0.398 & 0.252 \\
\hline SB 18 & 88 & 106.52 & 0.996 & 1.655 & 0.527 & 0.229 & 0.435 & 0.263 \\
\hline SB 19 & 163 & 216.01 & 0.887 & 2.003 & 0.534 & 0.215 & 0.403 & 0.267 \\
\hline SB 20 & 16 & 17.03 & 0.565 & 1.286 & 0.424 & 0.169 & 0.398 & 0.212 \\
\hline & & & & & & & & \\
\hline
\end{tabular}

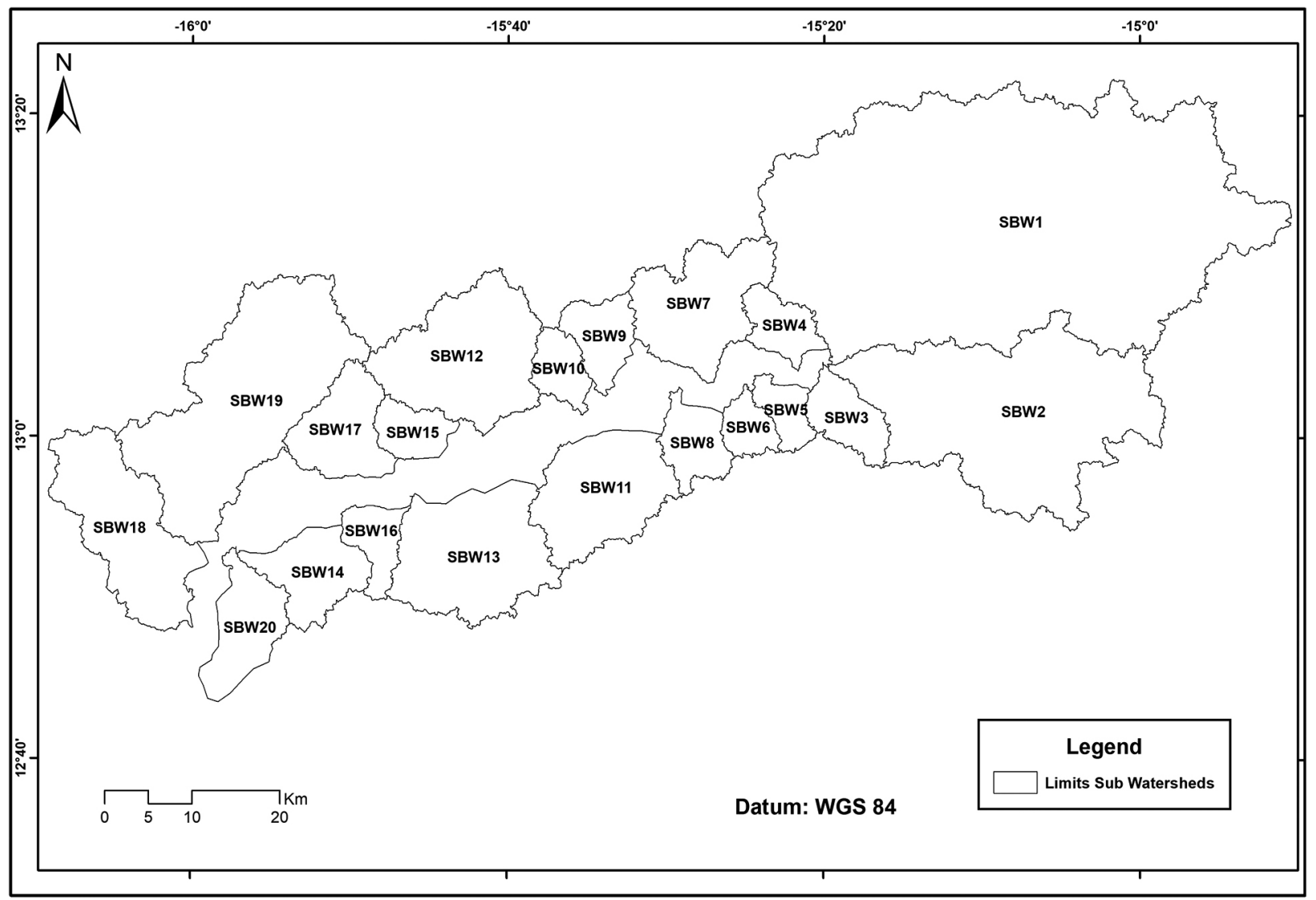

Fig. 2. Sub-basin division of the Soungrougrou basin. 


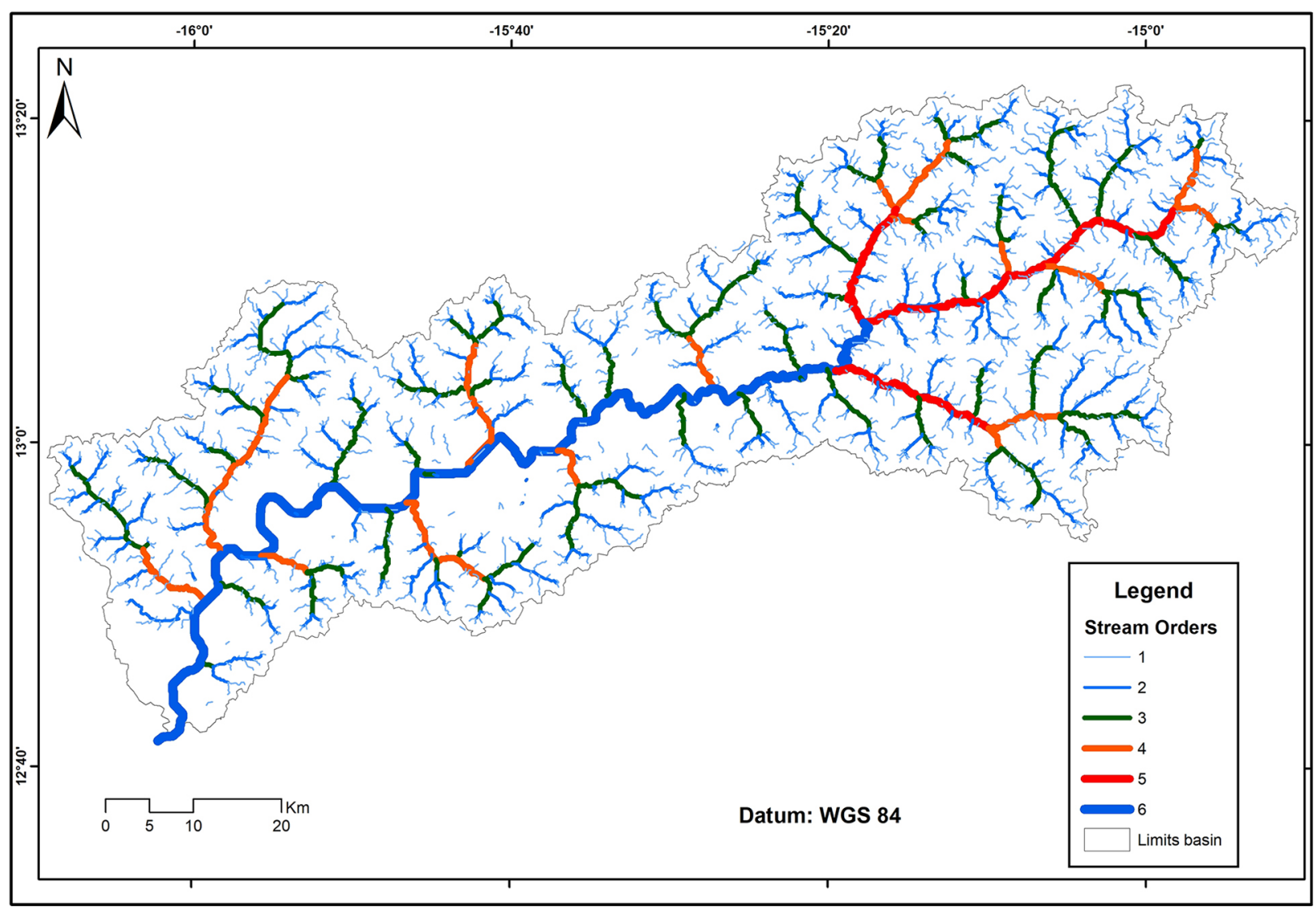

Fig. 3. Order of the rivers in the Soungrougrou basin.

The area along the main river is empty because it does not belong to any of the sub-watersheds. It belongs to the large basin of the main stream.

\section{River length ratio (Lur)}

The stream length ratio is the ratio of the average length of the stream of the selected order to the average length of the stream of the previous order in the catchment (Horton 1945). Variations in the length ratio between streams of different order indicate a late stage of geomorphological development (Singh, Singh 1997). There are variations in length ratio within and between sub-catchments (Table 2). This is due to variations in the slope and topography of the drained land (Waikar, Nilawar 2014). The average stream length ratio in the sub-catchments of the Soungrougrou ranges from 0.565 (for sub-catchment 20) to 2.576 (for sub-catchment 6) for a basin average of 1.272 .

\section{Bifurcation ratio $(\mathbf{R b})$}

The bifurcation ratio is the ratio of the total number of streams of the selected order to the total number of streams of the next higher order in the catchment. It is an index of relief and dissection (Horton 1945, Schumm 1956). The bifurcation ratio indicates the degree of integration between streams of different orders in a drainage basin. Lower values indicate the flatness or rolling physiography of the basin, while higher values indicate robust structural control over the drainage pattern with well-dissected drainage basins (Strahler 1980).

In most studies, the bifurcation ratio typically varies between 3 and 5 for the catchment in which the geology is reasonably homogeneous without structural disturbances of the drainage basin, which is the case of the Soungrougrou sub-catchments. The bifurcation ratios are classified into three different classes: circular basin $(\leq 2.25)$, oak-type basin (2.25 and 5) and elongated basin (>5). The average bifurcation ratio of the Soungrougrou sub-catchments is 1.898 for a total of 37.97. The bifurcation ratios vary from 1.125 (for sub-basin no. 8 which is a circular type basin) to 3.200 (for sub-basin no. 3 which is an oak-type basin) where the influence of geological 
structures on the drainage network is negligible (Verstappen 1983).

\section{Drainage density (Dd)}

The ratio of the total length of watercourses of all kinds to the area of the basin is defined as the drainage density and is expressed in $\mathrm{km} \times \mathrm{km}^{-2}$. Proximity in channel spacing can be identified by using the drainage density. This is useful for determining the quantitative measures of the average length of a river in relation to the whole basin. It is classified into five different classes: very coarse $(<1.2)$, low $(1.2$ to 2.4$)$, moderate (2.4 to 3.6), high (3.6 to 4.8 ) and very high (4.6 to 6$)$. Higher values indicate lower permeability, sparse vegetation and rough terrain, and lower values indicate higher permeability (Strahler 1964). The drainage density in all sub-catchments of the Soungrougrou is $<1 \mathrm{~km} \cdot \mathrm{km}^{-2}$, which is very coarse (i.e. limited) and indicates permeable subsoil, less dense vegetation cover and less rugged terrain (Nag 1998). Drainage density varies from 0.360 (for sub-basin 4) to 0.538 (for sub-ba$\sin 6$ ) with an average of 0.468 .

\section{Drainage texture $\left(\mathrm{km}^{2} \times \mathrm{km}^{-1}\right)(\mathrm{Tj})$}

Drainage texture (or torrentiality coefficient) determines the relative spacing between reaches in an eroded terrain. This depends on several natural factors, such as climate, rainfall, vegetation cover, soil type, infiltration capacity and terrain. The drainage texture of the watercourse assesses the suitability of a drainage basin for surface flow or infiltration. It is given in order I of flow and is subdivided into four different drainage categories, namely coarse $(<4)$, intermediate $(4-10)$, fine $(10-15)$ and ultra-fine $(>15)$. The drainage texture of the Soungrougrou sub-catchments varies from 0.055 (for sub-catchment 4) to 0.229 (for sub-catchment 18) with an average of 0.157 (Table 3). Thus, only one category of texture was found in the basin: coarse drainage (index $<4$ ).

\section{Flow frequency (Fs)}

The expression of the total number of stream segments of all orders per unit area is identified as the flow frequency or hydrographic density (Horton 1932). The flow frequency tends to be positively correlated with the drainage density. The flow frequency of the Soungrougrou sub-catchments varies from 0.153 (for sub-catchment 4) to
0.435 (for sub-catchment 18) with an average of 0.330 (Table 3). This low value of flow frequency indicates slower runoff and flooding in the catchment (Kale, Gupta 2001). Generally, a low flow frequency is related to permeable material. The low variation in flow frequency would be explained by the dominance of the Continental Terminal sandstone-clay formations of the sedimentary basin whose thickness series increases from east to west in the Soungrougrou sub-catchment (Faty 2011).

\section{Length of overland flow (Lg)}

Horton (1945) identifies the length of the stream on the ground surface before it concentrates in a stream channel. This is an independent variable that affects the development of the drainage basin. It can be equated to half the reciprocal value of the drainage density. The length of overland flow in the Soungrougrou sub-catchments varies from 0.180 (for sub-catchment 4 , indicating a fast runoff process) to 0.269 (for sub-catchment 9 , indicating a slow runoff process) with an average of 0.234 (Table 3).

In general, the linear parameters have a direct relationship with soil erosion because rivers are the dynamic agents of erosion. A high value indicates a high probability of soil erosion, which is the case for the majority of the Soungrougrou sub-catchments and particularly for sub-catchments 6,9 and 18 .

\section{Shape parameters}

The shape parameters include form factor, aspect ratio, compactness ratio and circulatory ratio (Table 4).

\section{Gravelius coefficient of compactness $\left(\mathrm{K}_{\mathrm{G}}\right)$}

The compactness index of Gravelius (1914) $\mathrm{K}_{\mathrm{G}}$ is defined as the ratio of the perimeter of the basin to the perimeter of the circle with the same area. This index is determined from a topographic map by measuring the perimeter of the catchment and its area. The compactness coefficient is defined as the perimeter of the basin divided by the circumference of a circle with the same area of the basin. It is proportional to the assessment of erosion risk, which requires the implementation of protection and conservation measures. The compactness coefficient is close to 1 for an almost circular watershed and higher than 1 when the 
Table 4. Shape parameters of the sub-catchments of the Soungrougrou catchment.

\begin{tabular}{|c|c|c|c|c|c|c|c|}
\hline $\begin{array}{c}\text { Sub- } \\
\text { basins }\end{array}$ & $\begin{array}{c}\text { Form } \\
\text { factor }(\mathrm{k})\end{array}$ & $\begin{array}{c}\text { Constant channel } \\
\text { maintenance (C) }\end{array}$ & $\begin{array}{c}\text { Gravelius Compactness } \\
\text { Coefficient (KG) }\end{array}$ & $\begin{array}{c}\text { Form } \\
\text { factor (Ff) }\end{array}$ & $\begin{array}{c}\text { Basin } \\
\text { shape (Bs) }\end{array}$ & $\begin{array}{c}\text { Circularity } \\
\text { ratio (Rc) }\end{array}$ & $\begin{array}{c}\text { Elongation } \\
\text { ratio (Ra) }\end{array}$ \\
\hline SB 1 & 2.111 & 2.100 & 2.086 & 0.372 & 2.689 & 0.226 & 2.679 \\
\hline SB 2 & 2.369 & 2.295 & 2.189 & 0.331 & 3.018 & 0.205 & 2.034 \\
\hline SB 3 & 2.297 & 2.444 & 1.676 & 0.342 & 2.926 & 0.350 & 1.210 \\
\hline SB 4 & 2.055 & 2.777 & 1.790 & 0.382 & 2.618 & 0.307 & 1.154 \\
\hline SB 5 & 2.250 & 2.566 & 1.700 & 0.349 & 2.866 & 0.341 & 1.039 \\
\hline SB 6 & 1.987 & 1.857 & 1.557 & 0.395 & 2.531 & 0.406 & 1.090 \\
\hline SB 7 & 1.200 & 1.991 & 1.911 & 0.654 & 1.528 & 0.270 & 1.824 \\
\hline SB 8 & 2.048 & 1.986 & 1.794 & 0.383 & 2.608 & 0.306 & 1.185 \\
\hline SB 9 & 1.742 & 2.055 & 1.710 & 0.451 & 2.219 & 0.337 & 1.268 \\
\hline SB 10 & 2.006 & 2.105 & 1.575 & 0.391 & 2.556 & 0.397 & 1.143 \\
\hline SB 11 & 1.411 & 2.169 & 1.795 & 0.556 & 1.798 & 0.306 & 1.729 \\
\hline SB 12 & 1.180 & 2.044 & 1.866 & 0.665 & 1.503 & 0.283 & 1.985 \\
\hline SB 13 & 1.600 & 2.061 & 1.917 & 0.491 & 2.038 & 0.268 & 1.749 \\
\hline SB 14 & 1.943 & 1.967 & 1.699 & 0.404 & 2.475 & 0.341 & 1.387 \\
\hline SB 15 & 1.568 & 2.277 & 1.518 & 0.501 & 1.997 & 0.427 & 1.235 \\
\hline SB 16 & 1.873 & 2.401 & 1.640 & 0.419 & 2.386 & 0.366 & 1.217 \\
\hline SB 17 & 1.520 & 1.984 & 1.500 & 0.516 & 1.937 & 0.438 & 1.485 \\
\hline SB 18 & 1.887 & 1.899 & 1.866 & 0.416 & 2.403 & 0.283 & 1.709 \\
\hline SB 19 & 2.058 & 1.872 & 2.005 & 0.381 & 2.622 & 0.245 & 1.989 \\
\hline SB 20 & 1.603 & 2.361 & 1.797 & 0.490 & 2.042 & 0.305 & 1.189 \\
\hline
\end{tabular}

watershed is elongated. It is classified into three different shape classes: squat (1 to 1.15), intermediate (1.15 to 1.5$)$ and elongated (1.5 and above). The values of the compactness coefficient of the Soungrougrou sub-catchments vary from 1.499 (for sub-catchment No. 17, indicating an intermediate shaped catchment) to 2.189 (for sub-catchment No. 2, indicating an elongated catchment) showing large variations across the sub-catchments (Table 4). According to this coefficient, sub-catchments 1, 2 and 19 are the most exposed to erosion risk.

\section{Form factor (Ff)}

The form factor (Ff) is the ratio of the basin area to the square of the basin length. The stream intensity of a unit area can be identified by this factor (Horton 1945). For a perfectly circular pond, the value of the form factor will be greater than 0.78 (a value of 1 would indicate a perfectly circular shape). The more elongated the pool, the lower the shape factor value would be (close to 0 ). The shape factor values of the Soungrougrou sub-catchments vary from 0.331 (for sub-catchment 2, indicating a more elongated catchment) to 0.665 (for sub-catchment 12 , indicating a more circular catchment) with an average of 0.445 (Table 4). The observation shows that sub-catchments 1 to 6 are highly elongated while sub-catchments $7,11,12$ and 17 are the least elongated.

\section{Basin shape (Bs)}

The shape of the basin is the ratio of the square of the basin length $(\mathrm{Lb})$ to the basin area (A). The shape values of the sub-catchments of the Soungroup Bs vary from 1.503 (for sub-catchment 12 , this corresponds to a lower flood flow) to 3.018 (for sub-catchment 2, this corresponds to a higher flood flow) with an average of 2.338 (Table 4). The Bs values of the sub-catchments (Table 4) indicate that sub-catchments 7,11 and 12 have lower flood discharge periods, while sub-catchments 1 to 5 have very high flood discharge.

\section{Circularity ratio (Rc)}

The circularity ratio defined by Miller (1953) is the ratio of the area of a pond to the area of a circle having the same circumference as the perimeter of the pond. This ratio is a dimensionless index used to identify the shape of the basin contour. The value varies from zero (a line) to one (a circle). The value tends to be influenced by the length and frequency of flows in their respective order, gradient, lithology and drainage pattern (Umrikar 2016). The circularity ratio values of the 
Soungrougrou sub-catchments vary from 0.205 (for sub-catchment No. 2, indicating a more elongated catchment) to 0.438 (for sub-catchment No. 17, indicating a more circular catchment) for an average of 0.320 (Table 4 ).

\section{Elongation ratio ( $\mathrm{Re})$}

The shape of a pond can be identified by the aspect ratio. It is calculated as the ratio of the diameter of a circle with a similar area to the basin to the maximum length of the basin (Schumm 1956). Various climatic and geophysical environments are evaluated between the ratio values of $0.60-1.00$. Values close to 1.00 indicate lower relief, while values between 0.60 and 0.80 may be associated with steep terrain slopes and high relief (Strahler 1964). The aspect ratio values of the Soungrougrou sub-catchments vary from 1.039 (for sub-catchment 5) to 2.679 (for sub-catchment 1) with an average of 1.515 (Table 4), indicating their often oval shape characterised by low relief, while some of the sub-catchments (1, 2, 7 and 19) fall into the elongated category.

Shape parameters such as elongation rate, form factor and compactness coefficient are inversely proportional to soil erosion vigour. Indeed, the low value of the shape parameter is the most determining and constitutes an indicator of erodability risk (Benzougagh et al. 2016).

\section{Relief aspects of the catchment area}

The relief or gradient aspects are quite essential parameters in the analysis of drainage basins as they describe the nature of the surface roughness and configuration. The relief ratio, relative relief and roughness index are some important parameters of the relief morphometry that are discussed in Table 5.

\section{Basin relief $(\mathbf{H})$}

Basin relief is defined as the difference in elevation between the lowest point (outlet) and the highest point (watershed) of a watershed (Kartic, Jatisankar 2013). It plays an important role in the development of landforms, surface drainage development and groundwater flow (Magesh, Chandrasekar 2012). The landform values of the sub-catchments of the Soungrougrou (Table 5) range from $56 \mathrm{~m}$ for sub-catchments 11 and 12 to $44 \mathrm{~m}$ for sub-catchment 4 . It can be seen that sub-catchments 1, 11, 12 and 18 have higher
Table 5. Aspect parameters related to the relief of the Soungrougrou sub-catchments.

\begin{tabular}{|c|c|c|c|c|}
\hline $\begin{array}{c}\text { Sub- } \\
\text { basins }\end{array}$ & $\begin{array}{c}\text { Basin } \\
\text { relief (Rh) }\end{array}$ & $\begin{array}{c}\text { Relief } \\
\text { ratio (Rhl) }\end{array}$ & $\begin{array}{c}\text { Relative } \\
\text { relief (Rr) }\end{array}$ & $\begin{array}{c}\text { Robust- } \\
\text { ness num- } \\
\text { ber (Rn) }\end{array}$ \\
\cline { 2 - 5 }$[\mathrm{m}]$ & {$\left[\mathrm{m} \mathrm{m}^{-1}\right]$} & {$[\%]$} & {$[-]$} \\
\hline SB 1 & 55 & 0.001 & 0.020 & 0.026 \\
\hline SB 2 & 50 & 0.001 & 0.028 & 0.022 \\
\hline SB 3 & 48 & 0.004 & 0.102 & 0.020 \\
\hline SB 4 & 44 & 0.004 & 0.102 & 0.016 \\
\hline SB 5 & 51 & 0.005 & 0.146 & 0.020 \\
\hline SB 6 & 50 & 0.005 & 0.152 & 0.027 \\
\hline SB 7 & 49 & 0.003 & 0.056 & 0.025 \\
\hline SB 8 & 52 & 0.005 & 0.114 & 0.026 \\
\hline SB 9 & 51 & 0.005 & 0.111 & 0.025 \\
\hline SB 10 & 46 & 0.004 & 0.125 & 0.022 \\
\hline SB 11 & 56 & 0.003 & 0.069 & 0.026 \\
\hline SB 12 & 56 & 0.003 & 0.055 & 0.027 \\
\hline SB 13 & 54 & 0.003 & 0.058 & 0.026 \\
\hline SB 14 & 51 & 0.003 & 0.088 & 0.026 \\
\hline SB 15 & 48 & 0.005 & 0.131 & 0.021 \\
\hline SB 16 & 50 & 0.005 & 0.119 & 0.021 \\
\hline SB 17 & 49 & 0.004 & 0.095 & 0.025 \\
\hline SB 18 & 55 & 0.002 & 0.058 & 0.029 \\
\hline SB 19 & 54 & 0.002 & 0.038 & 0.029 \\
\hline SB 20 & 50 & 0.006 & 0.123 & 0.021 \\
\hline
\end{tabular}

catchment relief and will therefore be exposed to high drainage, and low infiltration, as opposed to sub-catchments 3, 4, 15 and 17, which have lower catchment relief values.

\section{Relief ratio (Rhl)}

The relief ratio measures the overall slope of a drainage basin. It is an indicator of the intensity of the erosion process occurring in a catchment (Schumm 1956). One represents the horizontal and the other passes through the highest point of the basin. The relief ratio measures the overall slope of a drainage basin. It is an indicator of the intensity of the erosion process occurring in a catchment. It indicates the intensity of the erosion process taking place on the slope of that particular basin (Schumm 1956). The relief ratio is classified into 6 slope classes: no slope $(0-0.01)$, low slope (0.01-0.09), medium slope (0.09-0.25), fairly high slope (0.25-0.49), high slope (0.49-1) and very high slope (more than 1$)$. The values of the relief ratio of the Soungrougrou sub-catchments (Table 5) vary from 0.001 for sub-catchment no. 1 (indicating a lower slope) to 0.006 for sub-catchment no. 20 (indicating a steeper slope) for an average of 0.004 . The average value of the 
relief ratio in the Soungrougrou sub-catchment indicates a low relief and a gentle or no slope. The low relief ratio value is mainly due to the low degree of slope (Pareta, Pareta 2011).

\section{Relative relief $(\mathbf{R r})$}

The relative relief $(\mathrm{Rr})$ index is an important morphometric variable used for estimating the general morphological characteristics of the terrain (Umair, Syed 2014). Sub-catchments with higher relative relief have higher runoff potential than others (Umair, Syed 2014). The relative relief for the Soungrougrou sub-catchment of $0.04 \%$ corresponds to a low runoff potential. The relative relief values for the Soungrougrou sub-catchments vary from $0.020 \%$ (for sub-catchment No. 1, indicating a lower runoff potential than others) to $0.152 \%$ (for sub-catchment No. 6 , indicating a higher runoff potential than others) for an average of $0.089 \%$ (Table 5).

\section{Robustness number (Rn)}

The robustness number $(\mathrm{Rn})$ is the product of the drainage density (Dd) and the basin relief (Rh)
(Melton 1958, Strahler 1957) in the same unit. In some cases, both variables are significant, and the slope is both steep and long; this index of temporal robustness occurs in enormously high values. In the sub-catchments of the Soungrougrou, the values of the robustness index vary from 0.016 (for sub-catchment 4) to 0.029 (for sub-catchments 18 and 19) with an average of 0.024 (Table $5)$. These low values of the robustness number indicate that the area is not very sensitive to soil erosion.

\section{Digital elevation model (DEM)}

The term relative relief was introduced by Melton (1957). A visual analysis of the study area was carried out using a DEM. The DEM was produced based on contour data (Fig. 4). The relief of the Soungrougrou sub-basin is fairly uniform with very low altitudes overall. The highest point, at $78 \mathrm{~m}$, is in the extreme northeast of the basin. The minimum altitude of $0 \mathrm{~m}$ is noted towards the outlet. The relief consists of a tabular plateau, valleys and low-lying areas. The most frequent altitude class in the basin is

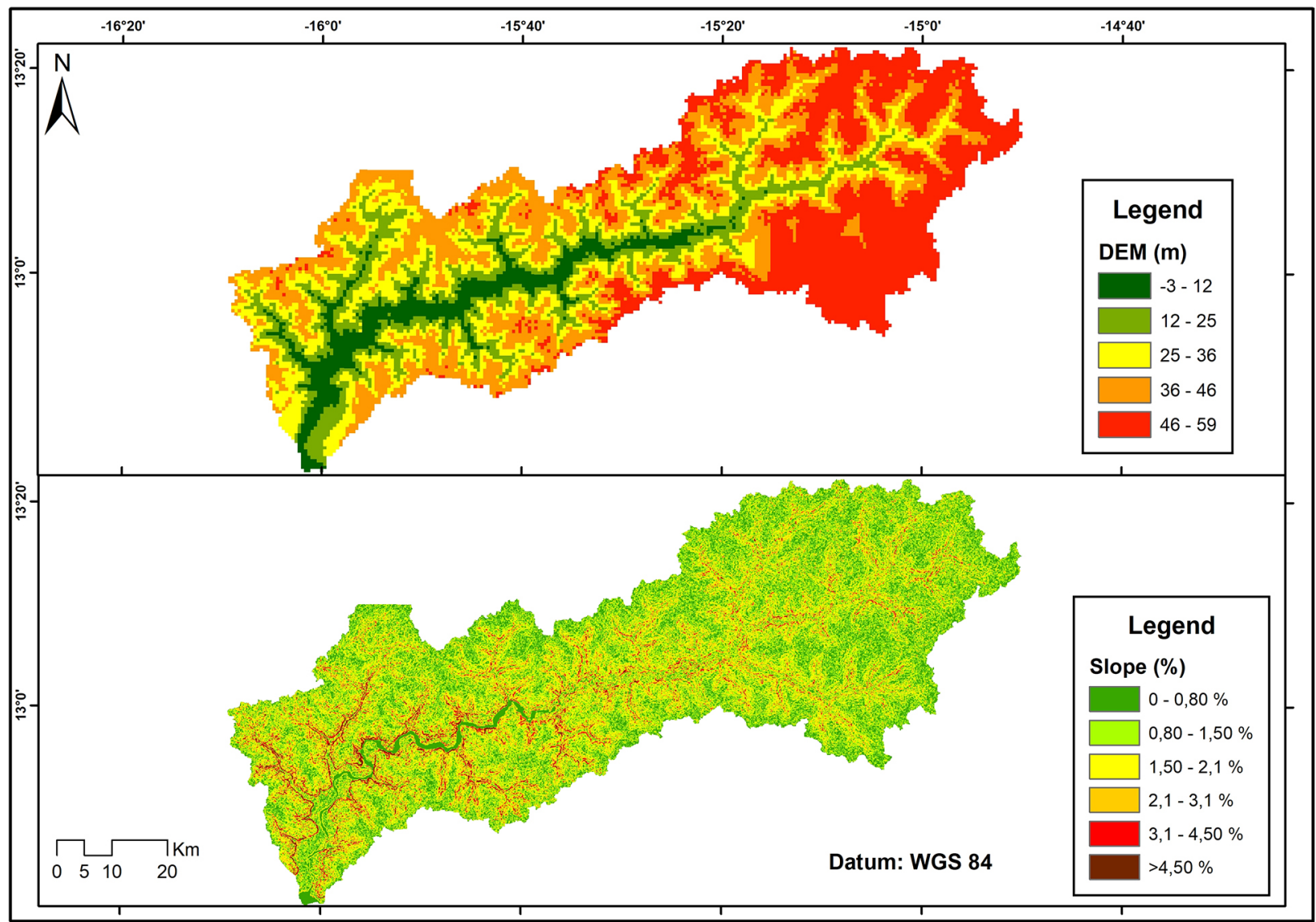

Fig. 4. Digital elevation model and slope [\%] of the Soungrougrou sub-basin. 
48-78 $\mathrm{m}$, which covers more than half of the ba$\sin$. The overall slope index of the Soungrougrou sub-basin is 0.31 for a specific difference in height of $19.29 \mathrm{~m}$, which indicates a low relief type. This is why the basin is exposed to low drainage and high infiltration.

\section{Slopes (m)}

Slope analysis is an essential factor in geomorphological studies (Horton 1940). Slope is defined as the rate of change in height of each cell relative to its neighbours (Todhunter 1888). Lithology and morphogenic climatic processes control the elements of slope in the region with varying strength. Understanding the slope plays an essential role in planning agriculture, deforestation and disaster management. Lower slope values indicate flat terrain and higher slope values indicate steeper terrain. The slope output dataset can be calculated as a percentage or degree of slope (Jensen 2004). In the Soungrougrou sub-catchment, the slope map is produced using the Arcgis platform. There are five slope classes identified and calculated in degrees. In the
Soungrougrou sub-catchment area, the slopes vary from $0^{\circ}$ to $13^{\circ}$. The southern part of the Soungrougrou sub-catchment area is observed as flat terrain and the northern part of the catchment area is covered by a residual plateau and hillock area (Fig. 4).

The analysis of the basin relief parameters (basin relief $(R b)$, relative relief $(R r)$, relief ratio $(R h)$ and robustness number $(\mathrm{Rn})$ ) allows us to draw the following conclusions: sub-basins No. 1, 11, 12 and 18 have high drainage and steeper slope, while sub-basins No. 3, 4, 15 and 17 have lower basin relief values.

\section{Land use and land cover analysis}

Land use and land cover mapping in the Soungrougrou basin show five classes: cropland and bare soil; open woodland (consisting of open forest and wooded savannah); very open woodland (consisting of wooded and shrubby savannah); and water and other (consisting of tans and slash and burn) (Fig. 5). Of all the classes, agricultural areas and bare soil are the most erodible.

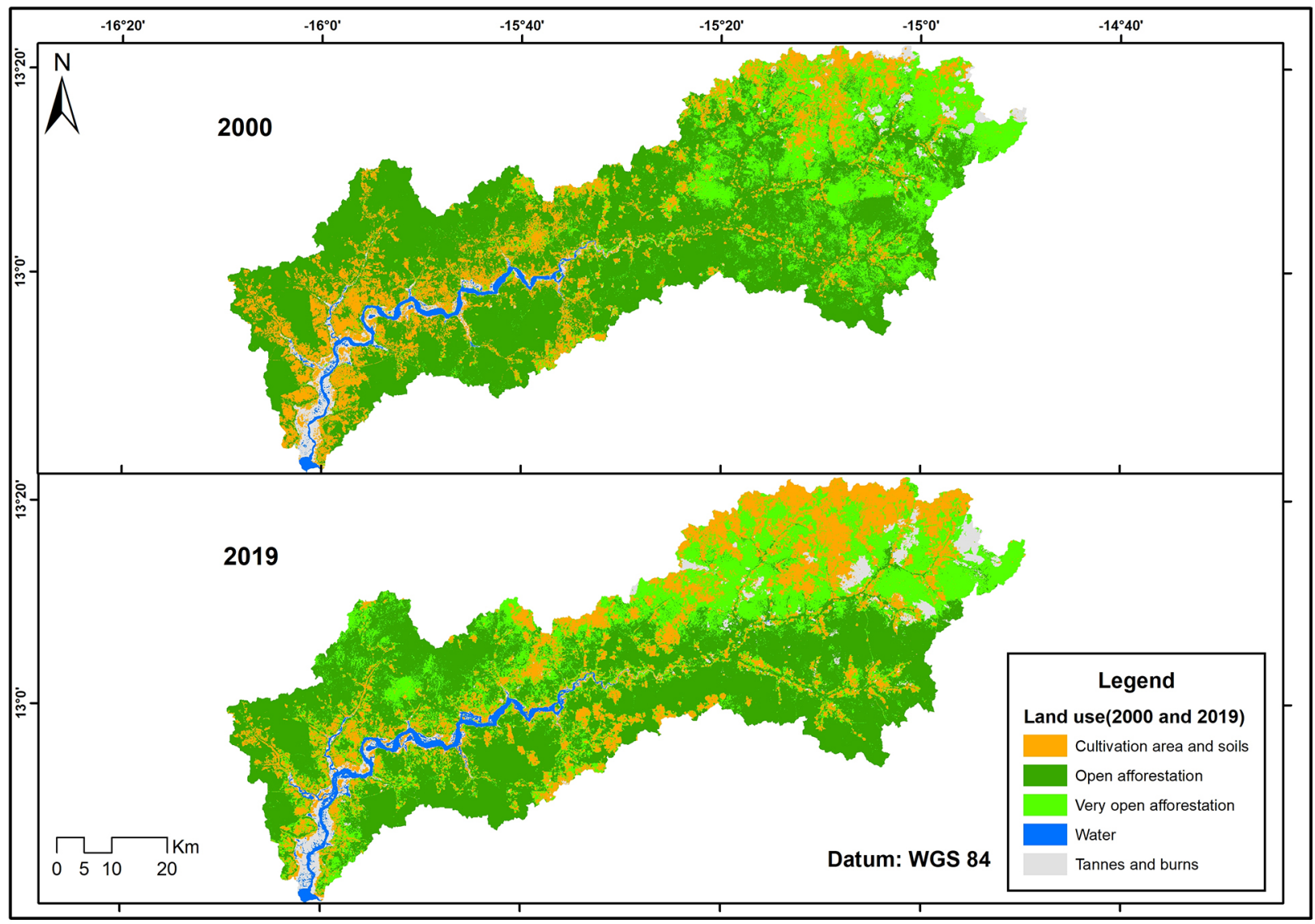

Fig. 5. Land use in the Soungrougrou basin in 2000 and 2019. 
These agricultural and bare soil areas occupied $892 \mathrm{~km}^{2}$ (18.6\%), $2719 \mathrm{~km}^{2}(56.7 \%), 933 \mathrm{~km}^{2}$ $(19.5 \%)$ and $164 \mathrm{~km}^{2}(3.4 \%)$ in 2000, respectively (Table 6). In 2019, the estimates were $3441 \mathrm{~km}^{2}$ $(72.8 \%)$ for open and very open woodland, $1036 \mathrm{~km}^{2}(21.6 \%)$ for cropland and bare soil, and $202 \mathrm{~km}^{2}(4.2 \%)$ for tannes and burnt areas. These estimates indicate that degraded forest and savannah are the dominant vegetation types in the Soungrougrou catchment. The Soungrougrou catchment as a whole presents a bleak scenario as land use and land cover changes between 2000 and 2019 indicate degradation of land and other natural resources. Variability of rainfall conditions, expansion of cultivated land, abusive and illegal wood cutting, demand for fuel-wood and energy and bushfires, among others, constitute unsustainable practices that seriously disturb forest ecosystems (Sané 2003, Solly et al. 2020).

Between 2000 and 2019, cropland and bare soil increased by $144 \mathrm{~km}^{2}$, very open woodland by $217 \mathrm{~km}^{2}$ and tans and slash and burn by $38 \mathrm{~km}^{2}$. On the other hand, open woodland has decreased by $428 \mathrm{~km}^{2}$. From 2000 to 2019, the conversion of areas to cropland and bare soil expanded by about $507 \mathrm{~km}^{2}(31 \%)$, while $528 \mathrm{~km}^{2}(69 \%)$ remained unchanged. Table 7 shows that a large proportion of the total area converted to cropland and bare soil was in open and very open woodland (94\%), with the remaining $6 \%$ coming from water, tannes and burnt areas. Open woodland is the class that lost the most area to cropland and bare soil $\left(230 \mathrm{~km}^{2}\right)$, very open woodland $\left(534 \mathrm{~km}^{2}\right)$ and mainly burnt areas $\left(37 \mathrm{~km}^{2}\right)$. Over the 19 years, $37.8 \%$ of land use and land cover changed.

(In the column, there are the land use classes that have gained areas over the other land use classes. In the line, there are the land use classes that have lost areas that are gained by the other land use classes indicated in the column).

As the Soungrougrou catchment is a typical rainfed catchment, where agriculture is the main land use activity that sustains the local population, an increase in cultivated areas and open and very open woodland can be seen as a positive change, as it is likely to bring environmental, economic and social benefits. Similarly, a decrease in cultivated areas, bare soil, tans and slash-andburn is also seen as a positive change as it indicates the recovery and rehabilitation of degraded and unproductive land. On the other hand, the decrease in the area of cultivated areas and open and very open woodlands can be considered as a negative change, indicating anthropogenic environmental degradation. Due to genetic pressures and the lack of conservation measures, the increase in cultivated areas and bare soil is also considered a negative change. A general decrease in the area of cultivated land and an increase in the area of uncultivated land are common in the sub-catchments from 10 to 20 , indicating a negative change. There is also a general decline in

Table 6. Area land use in 2000 and 2019.

\begin{tabular}{|l|r|r|r|r|r|r|}
\hline \multirow{2}{*}{\multicolumn{1}{c|}{ Land use }} & \multicolumn{2}{c|}{2000} & \multicolumn{2}{c|}{ Balance sheet } \\
\cline { 2 - 7 } & {$\left[\mathrm{km}^{2}\right]$} & {$[\%]$} & {$\left[\mathrm{km}^{2}\right]$} & {$[\%]$} & {$\left[\mathrm{km}^{2}\right]$} & {$[\%]$} \\
\hline Cultivated areas and bare soil & 892 & 18.6 & 1036 & 21.6 & 144 & 3.0 \\
\hline Open woodland & 2719 & 56.7 & 2291 & 47.8 & -428 & -8.9 \\
\hline Very open woodland & 933 & 19.5 & 1151 & 24.0 & 217 & 4.5 \\
\hline Water surface & 83 & 1.7 & 112 & 2.3 & 29 & 0.6 \\
\hline Other & 164 & 3.4 & 202 & 4.2 & 38 & 0.8 \\
\hline Total & 4791 & 100.0 & 4791 & 100.0 & - & - \\
\hline
\end{tabular}

Table 7. Matrix of land use changes between 2000 and 2019.

\begin{tabular}{|c|c|c|c|c|c|c|}
\hline \multirow[t]{2}{*}{ Classes } & $\begin{array}{c}\text { Cropland and } \\
\text { bare ground }\end{array}$ & Open woodland & Very open woodland & Water & $\begin{array}{c}\text { Tannes and } \\
\text { burn }\end{array}$ & Losses \\
\hline & \multicolumn{6}{|c|}{$\left[\mathrm{km}^{2}\right]$} \\
\hline Cropland and bare ground & 528.00 & 140.00 & 189.00 & 1.00 & 33.90 & 364.00 \\
\hline Open woodland & 230.00 & 1917.00 & 534.00 & 0.24 & 37.30 & 802.00 \\
\hline Very open woodland & 247.00 & 229.00 & 392.00 & 0.09 & 65.20 & 541.00 \\
\hline Water & 0.29 & 0.15 & 0.10 & 79.60 & 2.93 & 3.47 \\
\hline Tannes and burn & 30.40 & 4.40 & 35.50 & 31.00 & 63.00 & 101.00 \\
\hline Earnings & 507.00 & 374.00 & 759.00 & 32.50 & 139.00 & - \\
\hline
\end{tabular}


natural vegetation, i.e. open woodland, with the exception of sub-catchments 2 and 20, which reported a marginal increase in vegetation cover. Further analysis of land use/land cover change shows that sub-catchments $14,15,19$ and 20 reported a significant rate of negative change, showing strong environmental degradation.

\section{Prioritisation}

\section{Prioritisation based on morphometric analysis}

Linear morphometric parameters such as bifurcation ratio $(\mathrm{Rb})$, drainage density $(\mathrm{Dd})$, drainage texture $(\mathrm{Tj})$, stream frequency $(\mathrm{Fs})$ and surface flow length (Lo) and shape parameters such as shape factor (Rf), compactness coefficient $\left(\mathrm{K}_{\mathrm{G}}\right)$, basin shape (Bs), circularity ratio $(\mathrm{Rc})$ and elongation ratio $(\mathrm{Ra})$ are also called erosion risk assessment parameters and have been used to prioritise sub-catchments (Bidwas et al 1999, Benzougagh et al. 2016, Moharir et al. 2021). The linear morphometric parameters $(\mathrm{Bb}, \mathrm{Dd}, \mathrm{Tj}, \mathrm{Fs}$ and Lo) have a direct relationship with erodibility; the higher the value, the higher the erodibility. Therefore, for the ranking of the sub-catchments, the highest value of the linear parameters was ranked 1, the second-highest value was ranked 2 and so on, and the lowest value was ranked last. The shape parameters (Rf, $\mathrm{K}_{\mathrm{C}^{\prime}} \mathrm{Bs}, \mathrm{Rc}$ and $\mathrm{Ra}$ ) have an inverse relationship with erodibility (Nooka Ratnam et al. 2005); the lower the value, the higher the erodibility. Thus, the lowest value of the shape parameters was ranked 1 , the next lowest value was ranked 2 and so on, and the highest value was ranked last (Akram et al. 2009). Therefore, the ranking of sub-catchments was determined by assigning the highest priority/rank based on the highest value in the case of linear parameters and the lowest value in the case of shape parameters (Table 8). Once the ranking was done based on each parameter, the ranking values for all linear and shape parameters for each sub-catchment were added together for each of the 20 sub-catchments to obtain a composite value $(\mathrm{Cp})$. Based on the average value, those sub-catchments with the lowest assessment value were assigned the highest priority, the next highest value the second highest priority and so on. The sub-catchment with the highest $C p$ value was given the last priority. The sub-catchments were then classified into three priority categories: high (7.50-9.63), medium (9.64-11.78) and low (> 11.78). Thus, based on the morphometric analysis (Table 8 and Fig. 6), it is ascertained that $25 \%$ of the sub-catchments fall into the high priority $(6$, $8,14,17$ and 18$), 65 \%$ of the sub-catchments fall

Table 8. Results of the prioritisation of the morphometric analysis of the Soungrougrou sub-catchments.

\begin{tabular}{|c|c|c|c|c|c|c|c|c|c|c|c|c|}
\hline \multirow{2}{*}{ Sub-basins } & \multicolumn{5}{|c|}{ Linear parameters } & \multicolumn{5}{|c|}{ Shape parameters } & \multirow{2}{*}{ Cp value } & \multirow{2}{*}{ Final priority } \\
\hline & $\mathrm{Rb}$ & $\mathrm{Dd}$ & $\mathrm{Tj}$ & Fs & Lo & KG & Rf & Bs & Rc & $\mathrm{Ra}$ & & \\
\hline SB 1 & 2 & 11 & 14 & 13 & 11 & 19 & 7 & 17 & 2 & 20 & 11.6 & Low \\
\hline SB 2 & 13 & 15 & 15 & 15 & 15 & 20 & 1 & 20 & 1 & 19 & 13.4 & Low \\
\hline SB 3 & 1 & 18 & 18 & 19 & 18 & 6 & 2 & 19 & 15 & 7 & 12.3 & Medium \\
\hline SB 4 & 16 & 20 & 20 & 20 & 20 & 10 & 6 & 15 & 11 & 1 & 13.9 & Medium \\
\hline SB 5 & 17 & 19 & 19 & 18 & 19 & 8 & 3 & 18 & 13 & 1 & 13.5 & Medium \\
\hline SB 6 & 11 & 1 & 11 & 14 & 1 & 3 & 9 & 12 & 18 & 2 & 8.2 & High \\
\hline SB 7 & 5 & 7 & 4 & 4 & 7 & 16 & 19 & 2 & 5 & 16 & 8.5 & Medium \\
\hline SB 8 & 20 & 6 & 10 & 12 & 6 & 11 & 7 & 14 & 10 & 5 & 10.1 & High \\
\hline SB 9 & 14 & 9 & 6 & 2 & 9 & 9 & 13 & 8 & 12 & 10 & 9.2 & Medium \\
\hline SB 10 & 19 & 12 & 12 & 10 & 12 & 4 & 8 & 13 & 17 & 3 & 11.0 & Medium \\
\hline SB 11 & 8 & 13 & 13 & 11 & 13 & 12 & 18 & 3 & 9 & 14 & 11.4 & Medium \\
\hline SB 12 & 9 & 8 & 7 & 8 & 8 & 14 & 20 & 1 & 7 & 17 & 9.9 & Medium \\
\hline SB 13 & 10 & 10 & 8 & 9 & 10 & 17 & 15 & 6 & 4 & 15 & 10.4 & Medium \\
\hline SB 14 & 6 & 4 & 3 & 5 & 4 & 7 & 10 & 11 & 14 & 11 & 7.5 & High \\
\hline SB 15 & 3 & 14 & 16 & 16 & 14 & 2 & 16 & 2 & 19 & 9 & 11.1 & Medium \\
\hline SB 16 & 15 & 17 & 17 & 17 & 17 & 5 & 12 & 9 & 16 & 8 & 13.3 & Medium \\
\hline SB 17 & 4 & 5 & 5 & 7 & 5 & 1 & 17 & 4 & 20 & 12 & 8.0 & High \\
\hline SB 18 & 12 & 3 & 1 & 1 & 3 & 15 & 11 & 10 & 6 & 13 & 7.5 & High \\
\hline SB 19 & 7 & 2 & 2 & 3 & 2 & 18 & 5 & 16 & 3 & 18 & 7.6 & Medium \\
\hline SB 20 & 18 & 16 & 9 & 6 & 16 & 13 & 14 & 7 & 8 & 6 & 11.3 & Medium \\
\hline
\end{tabular}




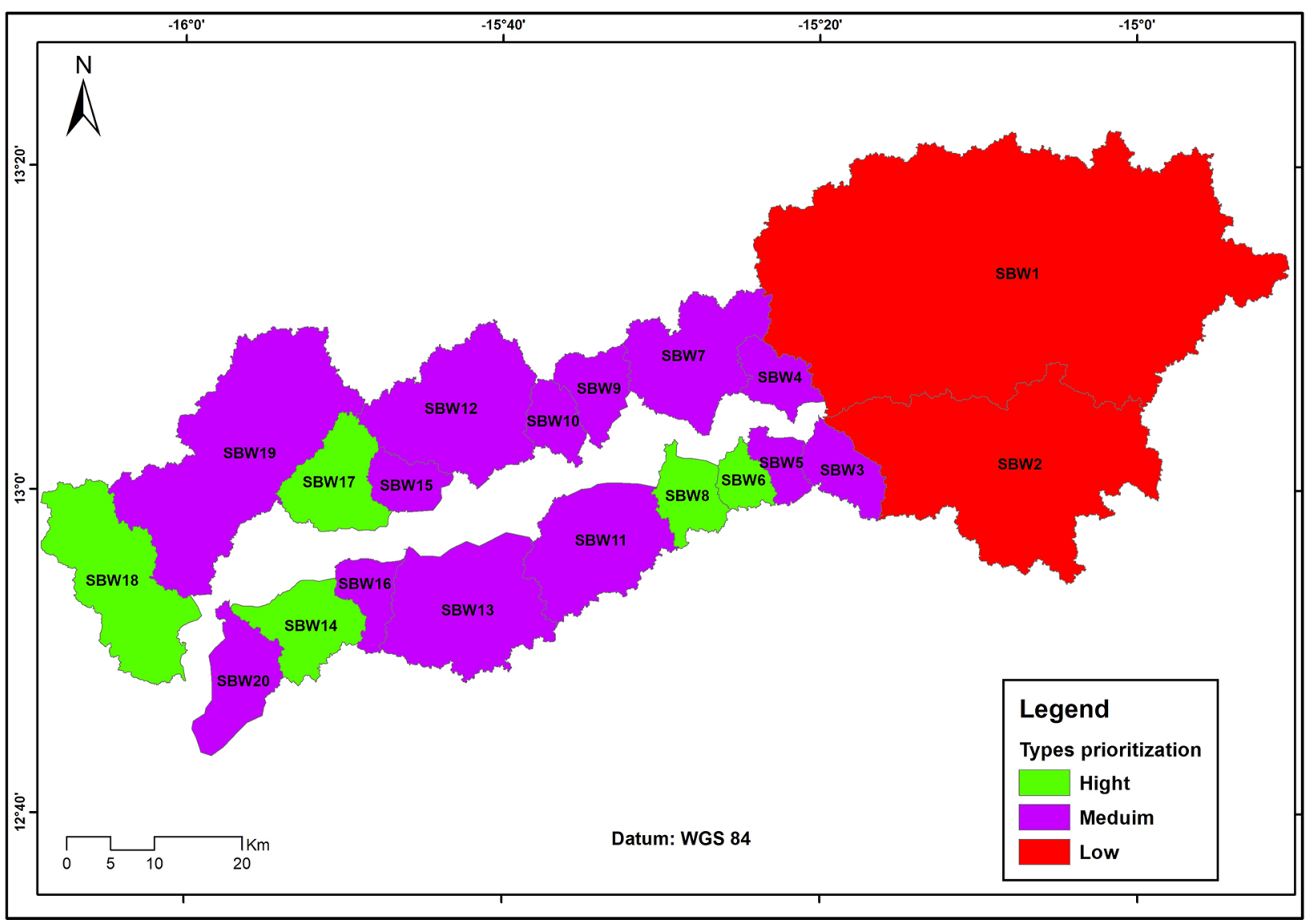

Fig. 6. Prioritisation based on morphometric analysis of the Soungrougrou sub-catchments.

into the medium priority $(3,4,5,7,9,10,11,12$, $13,15,16,19$ and 20 ) and only $10 \%$ into the low priority (1 and 2).

Morphometric analysis is one of the best methods to measure current water dispersion and erosion trends in the catchment. Geospatial technology also provides useful knowledge of natural resources and regional physical terrain parameters. Drainage patterns, drainage ordinances, catchment lines and other reserves in the study area were used in this analysis along with the remote sensing and geographic information system (GIS). In a variety of plans, geospatial and conventional sources are implemented with the ability to combine GIS and its analysis of spatial and multi-layered information, which are basic parameters for sustainable water resources planning.

\section{Prioritisation based on land use and land cover analysis}

The common land use categories, i.e. cropland, non-cropland, open and very open woodland, and slash and burn in the 20 sub-watersheds were taken into account to prioritise the sub-watersheds based on the analysis of land use and land cover changes. The change in area under each land use category was converted to a percentage and a ranking was assigned based on the area under each land use category (Table 9). Many of the sub-watersheds have shown negative changes in both cultivated and uncultivated land, i.e. there has been an overall increase in uncultivated land and tans and at the same time a decrease in the area of cultivated land between 2000 and 2019. However, tannes show some positive change, as their area has decreased in some sub-catchments $(3,5,9,10 \ldots)$, while there has been some increase in the area of open and very open woodland, reflecting a small positive change in some sub-catchments.

For the prioritisation of sub-catchments, the highest value (absolute value of the percentage difference in area between 2000 and 2019) in the categories of cropland use, uncultivated land, open and very open woodland, tans and burns 
Table 9. Results of prioritisation of area change in land use categories between 2000 and 2019 for the Soungrougrou sub-catchments.

\begin{tabular}{|c|c|c|c|c|c|c|c|c|c|c|}
\hline \multirow[b]{2}{*}{$\begin{array}{c}\text { Sub- } \\
\text { basins }\end{array}$} & \multicolumn{4}{|c|}{$\begin{array}{l}\text { Absolute value of the percentage difference } \\
\text { in land use area between } 2019 \text { and } 2000\end{array}$} & \multicolumn{4}{|c|}{ Prioritisation of land use change [\%] } & \multirow[b]{2}{*}{$\begin{array}{c}\mathrm{Cp} \\
\text { value }\end{array}$} & \multirow[b]{2}{*}{$\begin{array}{c}\text { Final } \\
\text { priority }\end{array}$} \\
\hline & $\begin{array}{c}\text { Cropped } \\
\text { areas and } \\
\text { bare soil }\end{array}$ & $\begin{array}{l}\text { Open } \\
\text { wood- } \\
\text { land }\end{array}$ & $\begin{array}{c}\text { Very } \\
\text { open } \\
\text { woodland }\end{array}$ & $\begin{array}{c}\text { Tannes } \\
\text { and burnt } \\
\text { land }\end{array}$ & $\begin{array}{l}\text { Cropped } \\
\text { areas and } \\
\text { bare soil }\end{array}$ & $\begin{array}{l}\text { Open } \\
\text { wood- } \\
\text { land }\end{array}$ & $\begin{array}{c}\text { Very } \\
\text { open } \\
\text { woodland }\end{array}$ & $\begin{array}{c}\text { Tannes } \\
\text { and burnt } \\
\text { land }\end{array}$ & & \\
\hline SB 1 & 14.81 & 13.67 & 4.05 & 3.64 & 2 & 6 & 3 & 1 & 3.00 & High \\
\hline SB 2 & 2.82 & 11.11 & 14.67 & 0.73 & 16 & 20 & 1 & 2 & 9.75 & Medium \\
\hline SB 3 & 4.35 & 0.50 & 4.74 & 0.10 & 13 & 17 & 2 & 10 & 10.50 & Medium \\
\hline SB 4 & 6.10 & 8.23 & 1.31 & 0.83 & 12 & 10 & 5 & 5 & 8.00 & Medium \\
\hline SB 5 & 8.05 & 9.24 & 1.43 & 0.24 & 10 & 8 & 6 & 14 & 9.50 & Medium \\
\hline SB 6 & 7.03 & 8.43 & 1.59 & 0.23 & 11 & 9 & 7 & 13 & 10.00 & Medium \\
\hline SB 7 & 12.97 & 45.97 & 32.30 & 0.69 & 4 & 1 & 20 & 7 & 8.00 & Medium \\
\hline SB 8 & 12.95 & 13.56 & 1.06 & 0.49 & 5 & 7 & 4 & 17 & 8.25 & Medium \\
\hline SB 9 & 3.93 & 21.12 & 18.59 & 0.21 & 14 & 3 & 16 & 11 & 11.00 & Medium \\
\hline SB 10 & 0.46 & 23.80 & 23.14 & 0.91 & 10 & 2 & 19 & 4 & 8.75 & Medium \\
\hline SB 11 & 8.39 & 13.80 & 5.63 & 0.24 & 9 & 5 & 9 & 15 & 9.50 & Medium \\
\hline SB 12 & 2.80 & 16.48 & 19.17 & 0.11 & 17 & 4 & 17 & 8 & 11.50 & Medium \\
\hline SB 13 & 2.37 & 4.46 & 2.74 & 0.35 & 18 & 16 & 8 & 16 & 14.50 & Low \\
\hline SB 14 & 10.42 & 1.60 & 9.24 & 0.04 & 6 & 18 & 11 & 9 & 11.00 & Medium \\
\hline SB 15 & 14.71 & 7.53 & 21.27 & 2.71 & 3 & 12 & 18 & 2 & 8.75 & Medium \\
\hline SB 16 & 2.86 & 7.46 & 10.49 & 0.21 & 15 & 13 & 13 & 12 & 13.25 & Low \\
\hline SB 17 & 1.46 & 7.66 & 9.68 & 0.60 & 19 & 11 & 12 & 19 & 15.25 & Low \\
\hline SB 18 & 9.70 & 2.15 & 7.46 & 0.76 & 7 & 19 & 10 & 20 & 14.00 & Low \\
\hline SB 19 & 8.76 & 5.42 & 14.32 & 0.50 & 8 & 14 & 15 & 18 & \begin{tabular}{|l|}
13.75 \\
\end{tabular} & Low \\
\hline SB 20 & 24.54 & 5.04 & 13.68 & 1.77 & 1 & 15 & 14 & 3 & 8.25 & Medium \\
\hline
\end{tabular}

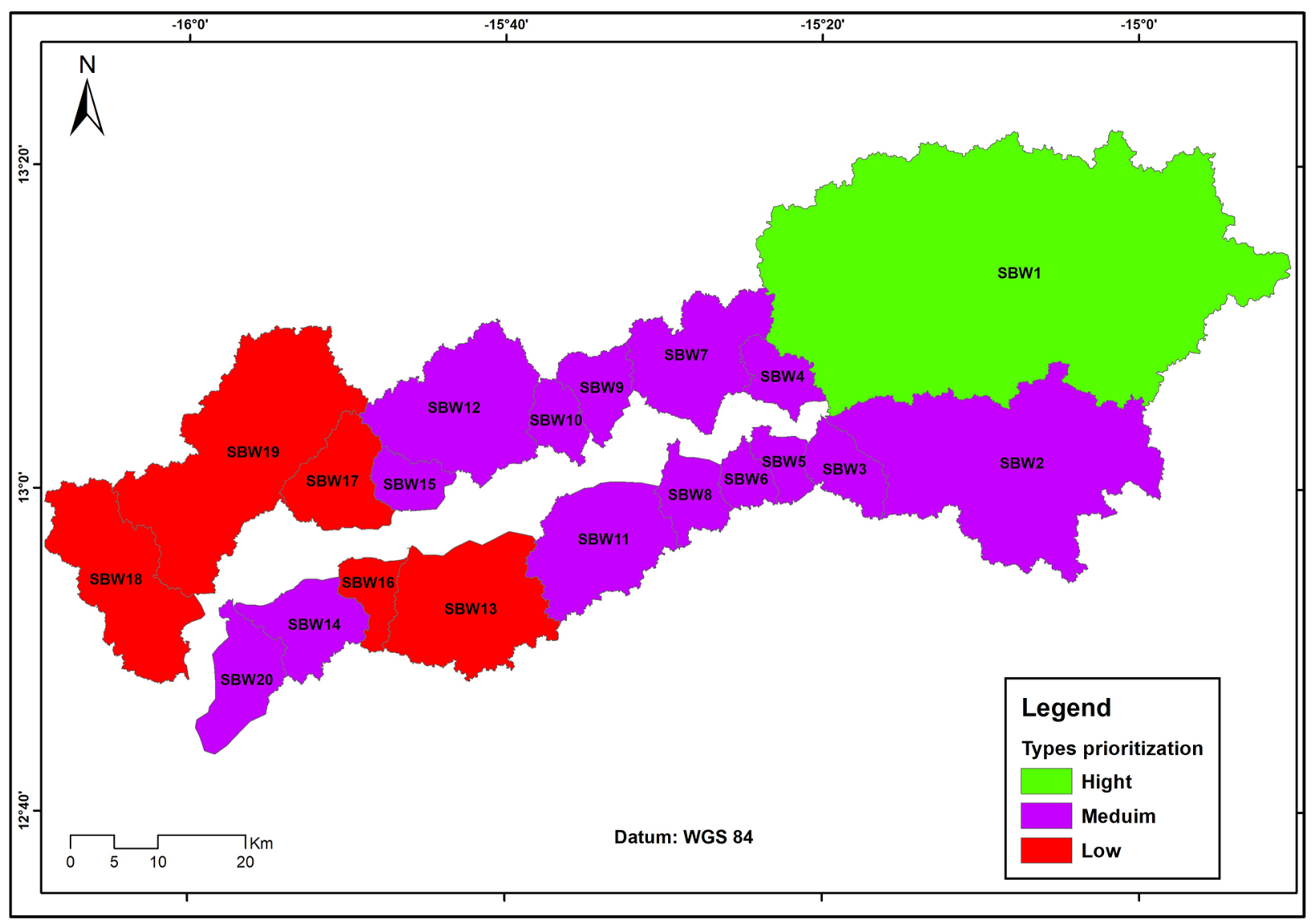

Fig. 7. Prioritisation based on percentage change in land use categories between 2000 and 2019 for the Soungrougrou sub-catchments. 
was ranked 1, the second-highest value was ranked 2 and so on. However, the lowest rank was given to the highest value among the land use categories showing a positive change, i.e. a decrease in slash and burn or an increase in open woodland/very open woodland (values in bold Table 9). Finally, the ranking under each land use was summed to obtain a composite value (Cp). The lower the $\mathrm{Cp}$ value, the higher the priority (Akram et al. 2009). The final ranking was given by classifying the highest and lowest range of $\mathrm{Cp}$ value into three classes: high priority (3.00-7.08), medium (7.09-11.18) and low (>11.18). Thus, based on the land use change analysis (Table 9 and Fig. 7), only $5 \%$ of the sub-basins (only one) fall into the high priority (1), $70 \%$ of the sub-basins fall into the medium priority $(2,3,4,5,6,7,8$, $9,10,11,12,14,15$ and 20$)$ and $25 \%$ into the low priority $(13,16,17,18$ and 19).

Bold type indicates land use categories (absolute value of the percentage difference in land use area between 2019 and 2000) showing positive change. For those land use categories showing positive change, the lowest rank was assigned to the highest value, unlike the rank given to land use categories showing negative change.

The results obtained from the morphometric analysis and the land use and land cover change analysis were correlated to determine the common sub-catchments under each priority. The correlation shows that sub-catchments 3, 4, 5, 7, $9,10,11,12,15$ and 20 have a medium priority based on the morphometric analysis and the land use and land cover analysis. However, the other sub-catchments show a low correlation and differ in their priority (high, low or medium) based on the morphometric analysis and the land use and land cover analysis.

\section{Conclusion}

The present study demonstrates the usefulness of remote sensing and GIS techniques in the prioritisation of sub-catchments based on morphometric analysis and land use change, as well as the integration of these two elements. In the current research, topographic maps, SRTM data (30 $\mathrm{m}$ resolution) were used for quantitative morphometric analysis. Remote sensing and GIS technologies have thus been more successful in understanding morphological features. This examination of parameter variations was carried out in the spatial, local and relief channels of the Soungrougrou catchment. Linear aspects of the catchment such as the bifurcation ratio indicate a normal catchment category and a homogeneous geology with structural disturbance. The stream length ratio changes arbitrarily at the basin and sub-catchment level with a change in slope and topography, which also indicates the late stage from youth to maturity of catchment development. It also reveals the relationship between the stage of erosion of the basin and the surface flow.

Aerial aspects such as drainage density are classified as moderate drainage density, which indicates that the catchment has a medium permeable subsoil. Form factor and circulatory ratio values indicate that the catchment is elongated. Relative relief aspects such as relative relief and robustness number show a low relief of the catchment. The sub-catchments were prioritised from rank 1 to rank 3, based on the result of the morphometric analysis. The weights of 10 linear and shape parameters were calculated, from which a composite value (Cp) was calculated. With these parameters, the sub-catchments are prioritised for soil erosion in vulnerable areas. Areas with high and low soil erosion potential are also identified using prioritisation. The relative proximity value of sub-catchments $6,8,14$, 17 and 18 is high, indicating high erosion-prone areas, while sub-catchments 1 and 2 have a low relative proximity value, indicating a low soil erosion area.

This study revealed that sub-basins 3, 4, 5, 7, $9,10,11,12,15$ and 20 are common sub-watersheds falling into the medium priority category based on morphometric analysis as well as land use and land cover; while for sub-basins 8, 14, 17 and 18, which fall into the high priority category only based on morphometric parameters, planners and decision makers can take conservation measures for specific local planning and development.

For the purposes of water management planning within a catchment area, it was useful to investigate the target water change for soil and water conservation measures or to complement water harvesting activities in the Soungrougrou sub-basin, a tributary of the Casamance basin in Senegal. 


\section{Funding}

This research was not funded, except for personal funds.

\section{Conflicts of interest/Competing interests}

The authors declare that there is no conflict of interest.

\section{Authors' contributions}

Cheikh Faye designed the project and wrote the article. Modou Ndiaye downloaded the satellite images, designed all the maps and corrected the document.

\section{Acknowledgements}

The authors thank the reviewers for their remarks and comments on the work.

\section{References}

Agarwal C.S., 1998. Study of Drainage Pattern through Aerial Data in Nahagarh Area of Varanasi District, U.P. Journal of the Indian Society of Remote Sensing 26(4): 169-175.

Akram J., Khan Imran K., 2012. Land use/land cover change due to mining activities in singrauli industrial belt, madhya pradesh using remote sensing and GIS. Journal of Environmental Research And Development 6(3A): 834-843.

Aouragh M.H., Ali E., 2014. Morphometric analysis of a Guigou Sub-Watershed, Sebou Basin, Middle Atlas, Morocco Using GIS Based ASTER (DEM). International Journal of Innovative Research in Science, Engineering and Technology 3(4): 11503-11512.

Benzougagh B., Boudad L., Dridri A., Sdkaoui D., 2016. Utilisation Du Sig Dans L'analyse Morphometrique Et La Prioritisation Des Sous-Bassins Versants De Oued Inaouene (Nord-Est Du Maroc). European Scientific Journal 12(6): 266-289.

Chopra R., Dhiman R., Sharma P.K., 2005. Morphometric Analysis of Subwatersheds in Gurdaspur District, Punjab Using Remote Sensing and GIS Techniques. Journal of Indian society of remote sensing 33(4): 531-539.

Chorley R.J., 1957. Illustrating the Laws of Morphometry. Geological Magazine 94: 140-150.

Clarke J.J., 1966. Morphometry from Maps, Essays in Geomorphology. Elsevier Publishing Company, New York: 235-274.

Dacosta H., 1989. Précipitations et écoulements sur le bassin de la Casamance. Dakar: ORSTOM, multigr. Thèse 3e cycle, Université Cheikh Anta Diop, Dakar.

Das A.K., Mukherjee S., 2005. Drainage Morphometry using Satellite Data and GIS in Raigad District, Maharashtra. Journal of the Geological Society of India 65: 577- 586.

Faye C., Solly B., Dièye S., 2020. Study of the fluctuation of the NDVI in the Casamance River Basin upstream of Kol- da using remote sensing data: What impact on flow? Nippon Journal of Environmental Science 1(2)1004: 1-13.

Gabale S.M., Pawar N.R., 2015. Quantitative morphometric analysis of Ambil Odha (Rivulet) in Pune, Maharashtra, India. IOSR Journal of Environmental Science, Toxicology and Food Technology 9(7): 41-48.

Gaikwad R., Bhagat V., 2018. Multi-criteria Prioritization for Sub-watersheds in Medium River Basin using AHP and Influence Approaches. Hydrospatial Analysis 2(1): 61-82.

Gajbhiye S., Sharma S.K., Meshram C., 2014. Prioritization of watershed through sediment yield index using RS and GIS approach. International Journal of $u$ - and e-Service, Science and Technology 7(6): 47-60.

Gashaw T., Tulu T., Argaw M., 2017. Erosion risk assessment for prioritization of conservation measures in Geleda watershed, Blue Nile basin, Ethiopia. Environmental Systems Research 6(1): 1-16.

Gebre T., Kibru T., Tesfaye S., Taye G., 2015. Analysis of watershed attributes for water resources management using GIS: The case of Chelekot micro-watershed, Tigray, Ethiopia. Journal of Geographic Information System 7(2): 177-190.

Gharde K.D., Kothari M., 2016. Hydromorphometric analysis and prioritization of Savitri Basin of Maharashtra, India using GIS. International Journal of Civil, Structural, Environmental and Infrastructure Engineering Research and Development 6(2): 1-10.

Gravelius H., 1914. Grundrifi der gesamten Gewcisserkunde. Band I: Flufikunde (Compendium of Hydrology, I. Rivers, in German). Goschen, Berlin.

Green K., Kempka D., Lackley L., 1994. Using remote sensing to detect and monitor land cover and land use changes. Photogramm. Engg. and Remote Sensing 60(3): 331-337.

Gumma M.K., Birhanu B.Z., Mohammed I.A., Tabo R., Whitbread A.M., 2016. Prioritization of watersheds across Mali using Remote Sensing data and GIS techniques for agricultural development planning. Water: 1-7.

Horton R.E., 1932. Drainage basin characteristics. Trans. Am. Geophysc. Union 13: 350-361.

Horton R.E., 1945. Erosional Development of Streams and their Drainage Basins: Hydro-physical Approach to Quantitative Morphology. Bulletin of the Geological Society of America 56: 275-370.

Horton R.E., 1940. An approach toward a physical interpretation of infiltration capacity. Proc. Soil Sci. Soc. Amer. 5: 399-417.

Jawaharraj N., Kumaraswami K., Ponnaiyan K., 1998. Morphometric Analysis of the Upper Noyil basin (Tamil Nadu). Journal of the Deccan Geographical Society 36: 1529.

Jensen J.R., 2004. Remote sensing of the environment: An earth resource perspective. University of South California. Éditeur: Pearson; 2nd édition (11 mai 2006).

Kale V.S., Gupta A., 2001. Introduction to Geomorphology. India: Orient Longman Ltd.: 82-101.

Kartic B., Jatisankar B., 2013. Prioritization of Watershed using Morphometric Analysis through Geoinformatics technology: A case study of Dungra subwatershed, West Bengal, India. Int. Journal of Advances in Remote Sensing and GIS 2(1): 2013.

Khan M.A., Gupta V.P., Moharana P.C., 2001. Watershed Prioritization Using Remote Sensing and Geographical Information System: A Case Study from Guhiya, India. Journal of Arid Environments 49: 465-475.

Langbein W.B., 1947. Topographic characteristics of drainage basins. Water Supply Paper 968-C: 125-157. 
Magesh N.S., Chandrasekar N., 2012. GIS model-based morphometric evaluation of Tamiraparani subbasin, Tirunelveli district, Tamil Nadu, India. Arabian Journal of Geosciences 7: 131-141. DOI 10.1007/s12517-012-0742-z.

Moharir K., Pande C., Pande R., 2021. Assessment of morphometric and hypsometric study for watershed development using spatial technology - a case study of Wardha river basin in Maharashtra, India. International Journal of River Basin Management 19(1): 4353. DOI: $10.1080 / 15715124.2018 .1505737$.

Manojkumar P.D., Nitin N.M., Akshada H.K., Ganesh M.D., 2019. Morphometric Analysis of Kolavadi Sub-Watershed in Bhor Tahsil Using GIS Techniques. J. Geographical Studies 3(1): 1-10.

Melton M.A., 1957. An analysis of the Relations among Elements of Climate, Surface Properties and Geomorphology. Columbia University, 389042 (11).

Melton M.A., 1958. Geometric properties of mature drainage basins and their representation in E4 phase space. J. Geol., 66, 1: 25-54.

Miller V.C., 1953. A quantitative Geomorphic Study of Drainage Basin Characteristic in the Clinch, Mountain Area, Verdinia and Tennessee. Tech Report 3 Office of Novel Research, Department of Geology, Columbia University, New York, 1-30.

Mueller J.E., 1968. An Introduction to the Hydraulic and Topographic Sinuosity Indexes. Annals of the Association of American Geographers 58(2): 372-385.

Nag S.K., 1998. Morphometric Analysis Using Remote Sensing Techniques in the Chaka Sub-basin, Purulia district, West Bengal. Journal of the Indian Society of Remote Sensing 26(1 and 2): 69-76.

Nooka Ratnam K., Srivastava Y.K., Venkateshwara Rao V., Amminedu E., Murthy K.S.R., 2005. Check Dam Positioning and Prioritization of Micro-Watersheds Using SYI Model and Morphometric Analysis-Remote Sensing and GIS Perspective. Journal of the Indian Society of Remote Sensing 33: 25-38.

Pareta K., Pareta U., 2011. Quantitative morphometric analysis of a watershed of Yamuna basin, India using ASTER (DEM) data and GIS. International Journal of Geomatics and Geosciences 2(1): 248-269.

Ratnam N.K., Srivastava Y.K., Venkateswarao V., Amminedu E., Murthy K.S.R., 2005. Check Dam Positioning by Prioritization of Micro-watersheds using SYI Model and Morphometric Analysis - Remote Sensing and GIS Perspective. Journal of the IndianSociety of Remote Sensing, 33(1): 25-28.

Reddy G.P.O., Maji A.K., Gajbhiye, K.S., 2004. Drainage Morphometry and its Influence on Landform Characteristics in a Basaltic Terrain, Central India - A Remote Sensing and GIS Approach. International Journal of Applied Earth Observation and Geoinformation 1-16.

Romshoo S.A., Bhat S.A., Rashid I., 2012. Geoinformatics for assessing the morphometric control on hydrological response at watershed scale in the Upper Indus Basin. Journal of Earth System Science 121(3): 311-335.

Schumm S.A., 1956. Evolution of Drainage System and Slope in Badlands of Perth Amboy, New Jersey. Bulletin of Geological Society of America 67: 597-646.

Singh S., Singh M.C., 1997. Morphometric Analysis of Kanhar River Basin. National Geographical Journal of India 43(1): 31-43.

Smart J.S., Surkan A.J., 1967. The relation between mainstream length and area in drainage basins. Water Resources Research 3(4): 963-974.

Sree devi P.D., Srinivasalu S., Kesavaraju K., 2001. Hydrogeomorphological and Groundwater Prospects of the Pageru River Basin by using Remote Sensing Data. Environmental Geology 40(8): 1088-1094.

Strahler A.N., 1950. Equilibrium theory of erosional slopes approached by frequency distribution analysis; Part II. American Journal of Science 248(11): 800-814. DOI 10.2475/ ajs.248.11.800.

Strahler A.N., 1957. Quantitative Analysis of Watershed Geometry. Transactions of American Geophysical Union 38: 913-920.

Strahler A.N., 1964. Quantitative Geomorphology of Drainage Basins and Channel Networks. In Chow, V. (ed.), Handbook of Applied Hydrology. McGraw Hill, New York: 439-476.

Strahler A.N., 1968. Quantitative Geomorphology. In Fairbridge, R.W (ed.), The Encyclopedia of Geomorphology. Reinhold Book Crop., New York.

Strahler A.N., 1980. Systems theory in physical geography. Physical Geography 1: 1-27.

Umair A., Syed A.A., 2014. Analysis of Drainage Morphometry and Watershed Prioritization of Romushi-Sasar Catchment, Kashmir Valley, India using Remote Sensing and GIS Technology. International Journal of Advanced Research 2(12): 5-23.

Umrikar B.N., 2016. Morphometric analysis of Andhale watershed, Taluka Mulshi, District Pune, India. Applied Water Science 7: 2231-2243.

Vittal S.S., Govindaonah S., Gowda H.H., 2004. Morphometric Analysis of Subwatersheds in the Pawagada Area of Tumkur District South India Using Remote Sensing and GIS Techniques. Journal of Indian Society of Remote Sensing 32(4): 351-362. 